\title{
Mathematics and science across the transition from primary to secondary school: a systematic literature review
}

\author{
Tandeep Kaur $^{{ }^{*}(\mathbb{D})}$, Eilish McLoughlin ${ }^{2}$ (D) and Paul Grimes ${ }^{1}$ (10)
}

\begin{abstract}
This study presents the findings from a systematic review of literature (1990-2020) of mathematics and science transition from primary to secondary education. The purpose of this review was to explore factors that influence students' experiences of mathematics and science transition from primary to secondary school, implications of these experiences and measures that have been used to support students during these transitions. In total, 73 publications related to mathematics transition and 47 publications related to science transition were analysed. Synthesis of findings identified three factors, namely student self-regulation, school and academic related, and social factors that contribute to shaping students' positive or negative experiences of mathematics and science transitions. The review findings suggest that no single factor can be attributed to influence students' experiences of mathematics and science transition and an interplay between various factors contributes to these experiences. The implications of difficult transition experiences were identified as shifts in students' academic achievement, attitudes towards mathematics and science and constructs related to identity development. Recommendations for future research are proposed to address gaps identified in current literature.
\end{abstract}

Keywords: Transition, Primary-secondary school, Mathematics transition, Science transition, Systematic review

\section{Introduction}

Education systems all over the world place a large emphasis on STEM (science, technology, engineering and mathematics) education. STEM education is recognised as an essential foundation not only for responsible citizenship, but also for twenty-first century challenges (Bybee, 2013; Maass et al., 2019). However, there are some concerns about lower student achievement in STEM subjects (Fraser et al., 2012), low uptake of STEM at the advanced level (Mullis et al., 2012; Perkins et al., 2013) and a shortage of STEM professionals affecting countries' economic prosperity (Bybee, 2013; Department of Education and Skills [DES], 2017; Kelley \& Knowles, 2016). While

\footnotetext{
*Correspondence: tandeep.kaur3@mail.dcu.ie

${ }^{1}$ Centre for the Advancement of STEM Teaching and Learning and School of STEM Education, Innovation and Global Studies, DCU Institute of Education, Dublin City University, Dublin, Ireland

Full list of author information is available at the end of the article
}

initiatives for promoting STEM education are undertaken internationally, the policy reforms are still in their embryonic stage (Anderson et al., 2020). As such, there is still an uncertainty about the understanding of effective STEM practices and related curricular supports (Maass et al., 2019). Many education systems still grapple with the challenge of preparing students for applying STEM learning to real-life problems (Bybee, 2013; Ritz \& Fan, 2015).

With an aim to inform gaps and identify measures to promote greater participation and interest of students in STEM learning, this review focuses on exploring students' experiences of two of the STEM disciplinesmathematics and science-across the transition from primary to secondary school. The sections below present an overview of literature on mathematics and science education in schools and on the challenges and opportunities for integrating mathematics and science learning. 
The last section discusses mathematics and science education through the lens of transition from primary to secondary school.

\section{Mathematics education}

The current landscape of mathematics education research draws a complex picture of mathematics as a discipline. While mathematics equips learners with skills required to understand the world around us through modelling both abstract and concrete problems (DES, 2017), the subject is criticised for curricular discontinuities at various education levels, resulting in gaps in student learning. As a result, many students feel disinterested in mathematics and very few students study mathematics at an advanced level or are interested in STEM related careers (West et al., 2010). Furthermore, many students suffer from anxiety in mathematics and lower self-esteem. In a large UK study by Devine et al (2018), $11 \%$ of primary school (8- to 9-year-old) and secondary school (12- to 13-year-old) students scored above average for 'moderate anxiety' on a maths anxiety rating scale. According to the Programme for International Student Assessment (PISA) 2015 results, one in five pupils had serious difficulties in developing sufficient mathematics or science skills (European commission, 2018; OECD, 2016).

Surprisingly, the anxiety related to mathematics appears as an age-old issue despite much research in this regard. Guillen (1984, p. 2) described mathematics anxiety as 'unabashed humility that mathematics evokes in hundreds of millions of people' (as cited in Deieso \& Fraser, 2019). Those who suffer from mathematics anxiety experience intense fear and worry while working with mathematics which impacts their cognitive development (Klee \& Miller, 2019). What is most concerning is that mathematics anxiety may begin at an early age and can have long-lasting impact (Aarnos \& Perkkila, 2012; Field et al., 2019; Ramirez et al., 2013).

A large body of research also highlights decline in attitudes towards mathematics with progress in levels of education (Deieso \& Fraser, 2019; Mudaly \& Sukhdeo, 2015; Paul, 2014; Widlund et al., 2018). It appears that despite many curricular and education reforms in mathematics, students still lack appreciation for mathematics and the picture of mathematics as a difficult subject remains unchanged. The PISA results for 2018 showed that on average across OECD countries, mean performance in mathematics and science did not change over the past two decades (OECD, 2019a). The report also revealed that on average across OECD countries, around one in four 15-year-olds did not attain a minimum level of proficiency in mathematics. These results suggest that a lot more needs to be done in relation to improvement in students' mathematics learning and attainment.

\section{Science education}

One of the most significant concerns in science education internationally is the declining numbers of students studying science at the advanced level and considering it for future careers (De Witt et al., 2014; Lyons \& Quinns, 2010; Potvin \& Hasni, 2014). The low uptake of science and aspirations for science-related careers has often been attributed to students' attitudes and their perceived utility of school science (DeWitt \& Archer, 2015; Regan \& DeWitt, 2015; Tai et al., 2006). Negative attitudes may decrease the likelihood of choosing science for future careers (Barmby et al., 2008; DeWitt \& Archer, 2015). However, it is also possible that positive science attitudes may sometimes not translate to science aspirations for the future (Jenkins \& Nelson, 2005). Archer et al. (2010) termed this phenomenon as the 'being-doing divide' articulating the disparity between 'enjoyment doing science' and 'becoming a scientist'.

A substantial body of research has raised concerns about lack of student interest and engagement in science (Anderhag et al., 2016; Osborne et al., 2003; Patrick \& Mantzicopoulos, 2015; Potvin \& Hasni, 2014; Tytler \& Osborne, 2012). It has been noted that a decline in students' attitudes towards school science occurs during adolescence (Barmby et al., 2008; Tytler \& Osborne, 2012). The most recent findings of the Trends in International Mathematics and Science Study (TIMSS) 2019 for science achievement of pupils in fourth and eighth grades in 64 participating countries also indicated that eighth grade students were less positive about learning science than fourth-grade students. The results indicated that overall, $38 \%$ of eighth graders were not confident in science which was twice the percentage of fourth graders who so reported. Furthermore, in countries teaching separate science subjects in eighth grade, students were much less positive and confident in learning Chemistry and Physics than Biology and Earth sciences (Mullis et al., 2020).

Research also highlights significant gender differences in science interest and attitudes with boys showing more preference for science as compared to girls (Barmby et al., 2008; Jenkins \& Nelson, 2005). Similar differences have been noted in relation to the career expectations. Even the academically high achieving girls are less likely to choose STEM careers in comparison to boys (Clewell \& Campbell, 2002; Wang et al., 2013). The PISA 2018 results indicated that on average across OECD countries, only $14 \%$ of girls who were top performers in science or mathematics reported that they expect to work as an 
engineer or science professional compared with $26 \%$ of top-performing boys who so reported (OECD, 2019b).

Addressing these concerns require effective measures to promote science interest in young students, especially the age group of 10-14 years, the age reported as a critical period for the formation of science aspirations of young children (DeWitt \& Archer, 2015; Lindahl, 2007; Tai et al., 2006; Tytler \& Osborne, 2012).

\section{Integrated learning of Mathematics and Science}

More recent research advocates the integration of STEM subjects to promote greater understanding of these subjects in real-world contexts (e.g. Margot \& Kettler, 2019; McLoughlin et al., 2020). Integrated STEM curricula allow the development of twenty-first century skills such as problem-solving and creativity, enabling students to appreciate and apply the learning to novel and unfamiliar situations (Honey et al., 2014). There have been various interpretations of STEM integration with debates on multidisciplinary, interdisciplinary and transdisciplinary approaches. A broad definition by Honey et al. (2014) contextualises integration as "working in the context of complex phenomena or situations on tasks that require students to use knowledge and skills from multiple disciplines" (p. 52). Kelley and Knowles (2016) define integrated STEM education as "the approach to teaching the STEM content of two or more STEM domains, bound by STEM practices within an authentic context for the purpose of connecting these subjects to enhance student learning" (p. 3). A common element in these interpretations is manifested in making transparent and meaningful connections between the subjects and real-world contexts to foster authentic student learning. Explicit connections between these two subjects offer opportunities to promote students' understanding and motivation for learning (English, 2016). A positive impact of the integration of mathematics and science on students' achievement has also been reported (Hurley, 2001). However, the complexity of such a process of integration has been realised by researchers (Honey et al., 2014; Kelley \& Knowles, 2016). In particular, a lack of flexibility in the secondary education curriculum has been noted (Honey et al., 2014). Some researchers have also pointed to the inequitable representation of the four disciplines in integrated STEM education; for example, criticisms around the underrepresentation of mathematics in STEM have been raised (English, 2016; Fitzallen, 2015). In fact, the STEM acronym is often used in reference to the science discipline only (English, 2016). Additionally, there may be challenges in relation to the integration approaches as the research on STEM integration in relation to curriculum and student learning outcomes is still in a developmental stage (English, 2016; Honey et al., 2014).
McLoughlin et al. (2020) propose an integrated approach to STEM Education to develop a range of STEM competences through addressing and solving real-world problems. The researchers emphasise the importance of innovative curriculum and pedagogical approaches for achieving STEM learning outcomes across the domains of knowledge, skills, attitudes and values. Kelley and Knowles (2016) suggest a greater focus on pedagogical practices along with an increased awareness of research findings on latest initiatives. However, the impact of integration on desired learning outcomes depends on whether these subjects are integrated completely throughout the lesson or one of these dominates in the lesson (Honey et al., 2014).

\section{Mathematics and science education through the lens of transition from primary to secondary school}

Transition from primary to secondary school has been described as the most challenging phase for students in their education. This transition involves significant changes in many aspects, such as, adjusting to new school environments, increased workload, change in teaching practices, friendship worries, experiences of bullying and higher expectations of secondary school teachers (Evangelou et al., 2008; Hammond, 2016; Jindal-Snape \& Foggie, 2008; Keay et al., 2015; Paul, 2014; West et al., 2010; Zeedyk et al., 2003). Positive experiences of primary to secondary school transition reported by students include making more friends, greater autonomy and freedom and challenging work in secondary school (Mackenzie et al., 2012; Mudaly \& Sukhdeo, 2015; Symonds \& Hargreaves, 2016).

Sdrolias and Triandafillidis (2008) comment that transition is both an opportunity and a problem. The experiences of transition, if negative, may impact not only on students' academic achievement, but also on their psychological well-being and can affect their self-esteem and self-concept (Symonds \& Galton, 2014; Yao et al., 2018; Zeedyk et al., 2003). Although these transition issues span across all the curricular disciplines, mathematics and science seem to be the most affected subjects. Studies have reported a significant decline in students' interest in mathematics and science as they progress to secondary education (Logan \& Skamp, 2008; Martin et al., 2015; Murphy et al., 2016; Varley et al., 2013.). As a result, motivation and interest for learning mathematics and science may decrease and students develop negative attitudes towards these subjects (Hasni et al., 2017; Martin et al., 2015; Paul, 2014; Tröbst et al., 2016; Yao et al., 2018). These attitudes strongly associate with their aspirations to study these subjects and may bring a significant dip in academic achievement (Barmby et al., 2008; DeWitt \& Archer, 2015; Widlund et al., 2018). Moreover, 
negative transition experiences also impact on students' emotional health and well-being, e.g. mathematics anxiety increases as students transition to secondary school (Suren \& Kandemir, 2020). Such negative transition experiences can strongly impede the development of students' mathematical and scientific identities and impact on their academic progression in these subjects.

\section{Scope of this review}

While many systematic reviews have explored general transition from primary to secondary school (for example, Jindal-Snape et al., 2019; McGee et al., 2003; Mumford \& Birchwood, 2020; Topping, 2011; van Rens et al., 2018), a comprehensive literature review specifically looking at transitions in the context of mathematics and science does not exist. This is particularly important given the international focus on increasing students' understanding and participation in mathematics and science, and more recently a focus on adopting integrated approaches to STEM teaching and learning (DES, 2017). To address this gap, this review focuses specifically on mathematics and science in the transition from primary to secondary school, and explores the measures indicated in literature for supporting students in their transition in these two subjects.

The key objective of this systematic review is to explore and compare the breadth of research on school transitions in mathematics and science. To achieve this, the review seeks to address the following research questions:

1. What factors influence students' experiences of mathematics transition from primary to secondary school?

2. What factors influence students' experiences of science transition from primary to secondary school?

3. What are the implications of the factors that influence students' experiences in mathematics across the transition from primary to secondary school?

4. What are the implications of the factors that influence students' experiences in science across the transition from primary to secondary school?
5. What measures have been used to support students in their mathematics and science transitions from primary to secondary school?

\section{Methodology}

A qualitative review of research on mathematics and science transition from primary to secondary school published during the period 1990-2020 was conducted. This systematic review was conducted in the following 4 stages, adapted from those proposed by Tranfield et al. (2003). A brief description of the steps involved in each stage is given in Table 1.

Multiple electronic databases were searched for relevant literature on primary to secondary school transition. The databases searched for the review were Academic Search Complete, Education research complete, British Education Index, Education Research Information Center (ERIC), and PsycINFO via EBSCOhost and Web of Science. The search involved the use of several keywords in combination. An example of a search string is

- (school trans*) AND (primary or elementary or junior or post-primary or secondary or middle or grade 7 or grade 8$)$.

Consideration was given to include the multitude of terms used interchangeably in literature. For example, the following string was used to search for the factors influencing transition.

- (issue* OR factor* OR predictor* OR determin* OR concern* OR impact* OR influenc* OR characteristic* OR effect* OR affect" OR challeng* OR barrier" OR support* OR hinder* OR intervention)

The following inclusion criteria was adopted for the search (Table 2).

The initial search yielded 6817 results. These results were then filtered for English language spanning the time 1990-2020 which gave 5075 results. The removal of duplicates from these results yielded 3736 publications.

Table 1 Stages of the review process. Adapted from Tranfield et al., 2003

\begin{tabular}{ll}
\hline Stage & Brief description of steps \\
\hline 1. Planning & $\begin{array}{l}\text { Formulation of research questions, planning of search and screening strategy, criteria for inclusion and exclusion of } \\
\text { studies }\end{array}$ \\
$\begin{array}{l}\text { 2. Conducting search, screening } \\
\text { and mapping }\end{array}$ & $\begin{array}{l}\text { Database search, Title and abstract screening, Classification of studies, Coding and Mapping of studies with relevant } \\
\text { research questions }\end{array}$ \\
$\begin{array}{l}\text { 3. Analysing and interpretation } \\
\text { Q. Reporting }\end{array}$ & $\begin{array}{l}\text { Presentation of results with respect to the research questions under study. Discussion of potential implications and } \\
\text { conclusions }\end{array}$ \\
\hline
\end{tabular}


Table 2 Inclusion criteria for systematic review

\begin{tabular}{ll}
\hline Aspect & Criteria \\
\hline Language & English \\
Time span & $1990-2020$ \\
Relevance & Primary to secondary school \\
& transition focused \\
Age group & $10-16$ years \\
Geographical location & Any \\
Research method & Quantitative, qualitative, mixed \\
Publication types & Peer-reviewed publications \\
\hline
\end{tabular}

The first step of filtration involved the screening of titles and abstracts of these 3736 publications for their inclusion or exclusion according to the review protocol. The title and abstract screening yielded 758 results. A manual search of literature resulted in 17 additional publications for inclusion. This gave 775 publications for review at the first stage. Figure 1 illustrates the number of publications yielded at each stage of the search process.

The final 775 publications obtained after the screening of titles and abstracts were classified by disciplines. As the main focus of this review is on mathematics and science transitions, studies in other disciplines, e.g. History, Music, Physical education and Visual Arts were all grouped under 'other disciplines'. Thus, the final classification of studies was reported under five discipline groups-Mathematics, Science, Multidisciplinary (including Mathematics and Science), Other disciplines (excluding Mathematics and Science) and General (nondiscipline specific) (in Table 3).

These 775 studies were screened to identify research trends relating to transitions between primary and second level. In the first step, open coding was conducted, and initial codes were determined as a result of this process. These initial codes were chosen to reflect the primary focus of each study. Similar initial codes were

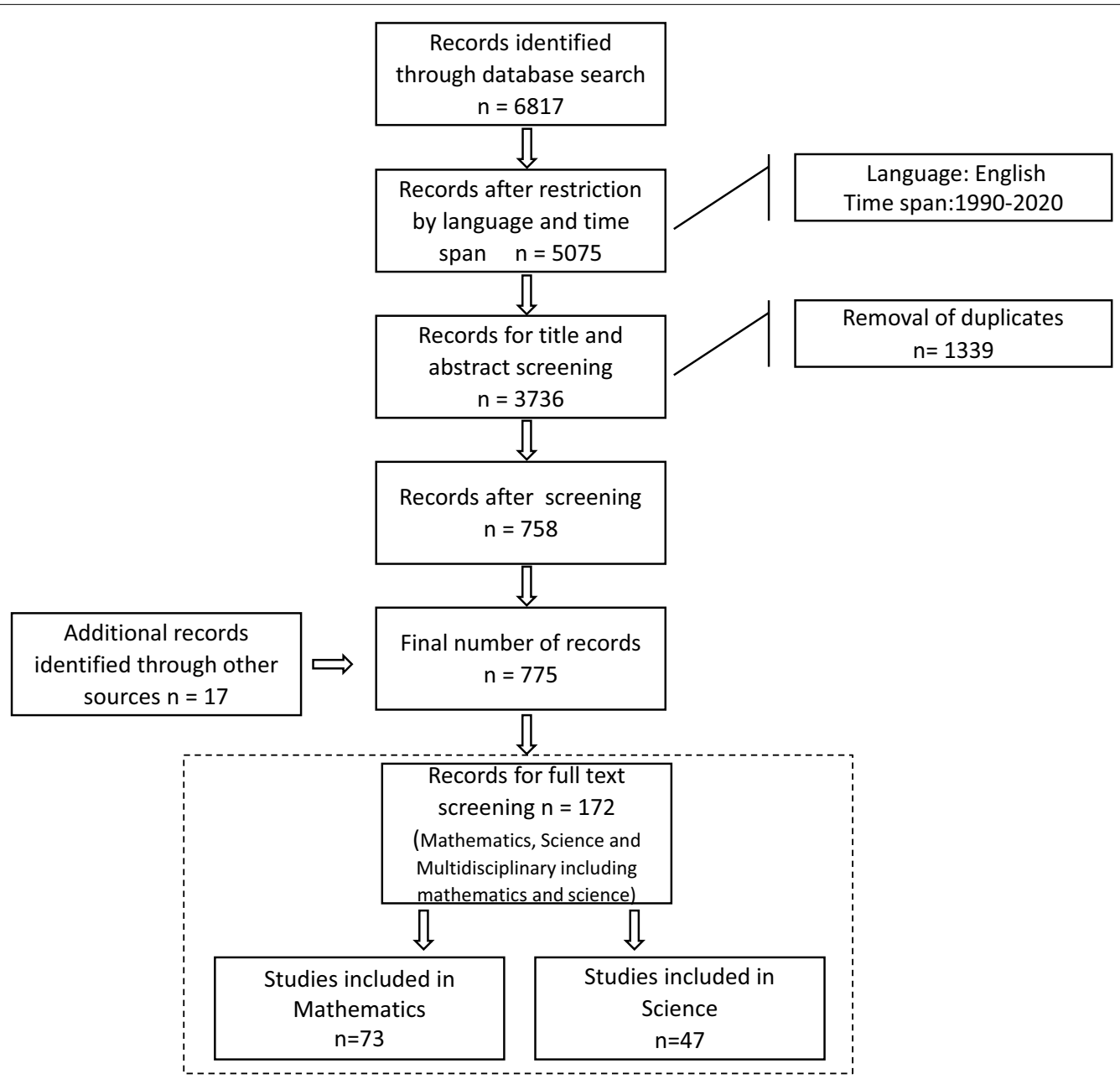

Fig. 1 Stages of search process for systematic review 
Table 3 Identification of codes after screening 775 publications

\begin{tabular}{|c|c|c|c|c|c|c|}
\hline Code & Mathematics & Science & $\begin{array}{l}\text { Multidisciplinary } \\
\text { (including mathematics } \\
\text { and science) }\end{array}$ & $\begin{array}{l}\text { Other disciplines } \\
\text { (excluding mathematics } \\
\text { and science) }\end{array}$ & $\begin{array}{l}\text { General/non- } \\
\text { discipline } \\
\text { specific }\end{array}$ & Total \\
\hline Academic performance context & 18 & 5 & 6 & 5 & 19 & 53 \\
\hline Learning environment & 15 & 3 & 4 & 1 & 15 & 38 \\
\hline Curriculum, content and pedagogy & 14 & 24 & 0 & 1 & 2 & 41 \\
\hline Teachers'influence & 14 & 4 & 0 & 4 & 23 & 45 \\
\hline School and policy context & 1 & 0 & 1 & 2 & 26 & 30 \\
\hline $\begin{array}{l}\text { Socio background, family, externali- } \\
\text { zation }\end{array}$ & 9 & 2 & 3 & 8 & 132 & 154 \\
\hline $\begin{array}{l}\text { Self-regulation and psychological, } \\
\text { internalization }\end{array}$ & 21 & 10 & 10 & 27 & 224 & 292 \\
\hline Gender & 4 & 1 & 1 & 1 & 16 & 23 \\
\hline Specialised student groups & 2 & 0 & 0 & 3 & 94 & 99 \\
\hline Total & 98 & 49 & 25 & 52 & 551 & 775 \\
\hline
\end{tabular}

combined to identify nine distinct codes, as shown in Table 3. For example, the initial codes of teacher content knowledge, teacher collaboration, teachers' beliefs and perspectives were combined to form the final code Teachers' influence.

As illustrated in Table 3, most of the research on transition across primary to secondary school focuses on general aspects and were not discipline focused. There is notably a greater number of research studies focussing on transition in mathematics $(N=98)$ than science $(N=49)$. Also, the majority of the studies report on students' selfregulation and internalization, such as self-esteem, selfconfidence, motivation, attitudes and constructs related to identity development. The code labelled as socio background, family and externalization has the second highest number of research publications in the selected set of literature and includes factors based on relationships with parents and peers, social background, race, ethnicity and socio-economic status (SES).

The next stage of the review involved screening the full text of each publication classified under the disciplines of Mathematics, Science, and Multidisciplinary (including Mathematics and Science). All of the publications coded as Mathematics $(N=98)$, Science $(N=49)$ or Multidisciplinary including Mathematics and Science $(N=25)$, were further screened to map them to the research questions 1-5 of this review. As the focus of the review was on transitions in mathematics and science, it was decided that studies that focussed only on specific or specialised contexts (e.g. special education needs, ethnic groups) would not be included as these findings may not be generalisable. From the 25 studies coded as Multidisciplinary (including Mathematics and Science), 9 studies met the inclusion criteria for the review. None of these 9 studies addressed an integrated learning approach to mathematics and science. Therefore, relevant findings pertaining to both disciplines were extracted from these studies and discussed in relation to transitions in mathematics or science. This screening process resulted in the identification of 73 publications on mathematics transition and 47 publications on science transition that met the review criteria. This formed the corpus of studies that are discussed in this review. The final stage of the review process was to read the full text of each publication. The findings of each of these studies were extracted and analysed in relation to each research question. Some studies addressed more than one research question. In such cases, the studies were coded for all relevant research questions $1-5$.

In relation to research questions 1 and 2 , initial factors that influence students' experiences of mathematics/science transition from primary to secondary school were identified. Similar factors were grouped together to form three distinct categories of factors-(i) student self-regulation, (ii) school and academic related and (iii). social factors. For example, factors relating to students' self-esteem, self-confidence, motivation, etc., were grouped together to form the category Student Self-Regulation (see Tables 6 and 7). A similar process was used to identify the implications of these factors in relation to research questions 3 and 4 (see Tables 8 and 9).

The next section presents an overview of research on transitions in mathematics and science and the findings in relation to each of the research questions $1-5$.

\section{Findings}

An overview of the trends in research publications on transitions in mathematics and science is presented followed by the review findings from research questions 1 to 5 . 


\section{Overview of research on transitions in mathematics}

The 73 studies identified were analysed to explore research publication trends. Figure 2 illustrates an upward trend in the number of publications in mathematics transition from the year 1990 to 2020 for the selected sample of 73 papers.

However, most of the selected studies focused on students' negative experiences of transition which echoes the findings from other literature reviews on transitions (e.g. Jindal-Snape et al., 2019). The majority of these studies focussed on the cause-effect relationship between variables for the issues related to transition. Only three studies addressed measures to support student learning across mathematics transitions. From the 73 studies selected for review, around $36 \%(N=26)$ of the studies were conducted in the European context, $30 \%(N=22)$ of the studies were conducted in the US and the remaining $34 \%(N=25)$ spanned diverse international regions. Table 4 shows a summary of the selected set of studies on mathematics transition



in terms of their primary focus, research design and research approach.

As depicted in Table 4, more than $60 \%$ of the studies $(N=47)$ studies employed a longitudinal design where students were followed over their transition to secondary school for duration of time ranging from 3 months to 4 years. A cross-sectional research design was used in 26 studies which included seven studies on teachers' perspectives around transition. The research method used in the majority of the studies (around $70 \%, N=50$ ) was quantitative, with the most common tool of data collection as participants' self-reported questionnaires. Although the reliability of surveys self-reported by students has been questioned in the literature, large sample sizes of participants recruited in most of the longitudinal studies explain this trend. From the remaining studies, 8 studies used qualitative methods of research and 15 studies adopted a mixed methods approach to support their findings from the quantitative analysis. While the majority of studies collected data from students, studies collecting parents' views are very few. Figure 3 shows the distribution of participants in study samples.

\section{Overview of research on transitions in science}

47 studies focused on science transition from primary to secondary school were identified. The trend in publication of research on science transition from 1990 till 2020 is shown in Fig. 4.

The graph suggests that there has been an increasing attention in research on primary-secondary science transition since 2000. From the 47 studies reviewed in science, 23 studies were conducted in the European context-14 from the UK, 3 from Ireland, 2 from Northern Ireland, 3 from Germany and 1 from Sweden. From the remaining 24 studies, 9 studies were conducted in the US and 15 studies spanned diverse international regions. Table 5 displays a summary of the selected studies

Table 4 Summary of reviewed studies on mathematics transition

\begin{tabular}{|c|c|c|c|c|c|c|}
\hline \multirow[t]{2}{*}{ Code } & \multirow{2}{*}{$\begin{array}{l}\text { Number of } \\
\text { articles }\end{array}$} & \multicolumn{2}{|c|}{ Research design } & \multicolumn{3}{|c|}{ Research approach } \\
\hline & & Longitudinal & $\begin{array}{l}\text { Cross- } \\
\text { sectional }\end{array}$ & Quantitative & Qualitative & Mixed \\
\hline Academic context & 11 & 10 & 1 & 8 & 0 & 3 \\
\hline Learning environment & 16 & 12 & 4 & 9 & 2 & 5 \\
\hline Curriculum, content and pedagogy & 8 & 4 & 4 & 4 & 4 & 0 \\
\hline Teachers'influence & 8 & 1 & 7 & 4 & 1 & 3 \\
\hline Family, externalization & 2 & 2 & 0 & 2 & 0 & 0 \\
\hline $\begin{array}{l}\text { Self-regulation and psychological, inter- } \\
\text { nalization }\end{array}$ & 24 & 17 & 7 & 20 & 1 & 3 \\
\hline Gender & 4 & 1 & 3 & 3 & 0 & 1 \\
\hline Total & 73 & 47 & 26 & 50 & 8 & 15 \\
\hline
\end{tabular}




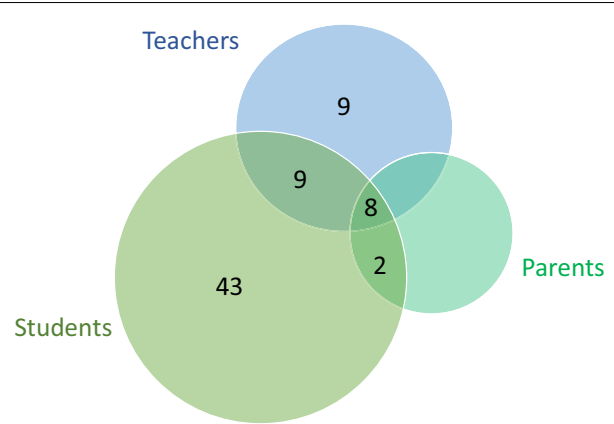

Fig. 3 Distribution of participants in study samples in mathematics transition

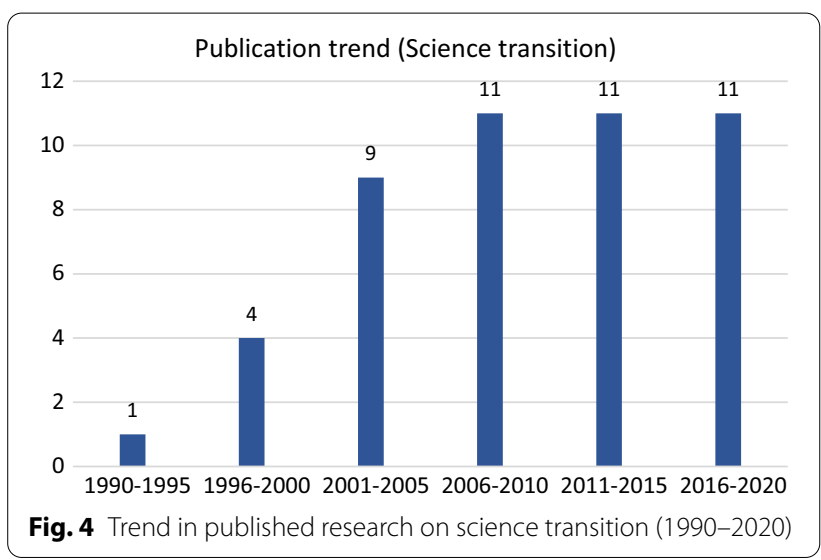

on science transition in terms of their primary focus, research design and research approach.

In contrast with the trends in mathematics transition research, more studies employed a cross-sectional research design here (Table 5). A cross-sectional research design was used in 29 studies and there is a balanced proportion of studies using quantitative, qualitative and mixed method approaches for data collection and analysis. Also, the majority of the studies investigated the domain of curriculum, content and pedagogy. This included investigation of the effects of cooperative learning in science, students' understanding for the concepts of Energy, Heat and Matter and the effect of instructional practices on students' science interest and cognitive development across transition. The participant sample mostly consisted of either students or a mix of students and teachers. Figure 5 shows the distribution of participants in the studies selected for review on science transition.

\section{Research Question 1. What factors influence students' experiences of mathematics transition from primary to secondary school?}

As described in the methodology section, the review identified three broad categories of factors that influence students' experiences of mathematics transition from primary to secondary school. These are-(i) student self-regulation, (ii) school and academic related and (iii) social factors. The category of student self-regulation includes factors related to behaviours, beliefs and/or emotions that could influence an individual's experiences (positive or negative) in transitions. For example, emotions or feelings about self, school belongingness, motivation, and engagement. The school and academic factors include aspects relating to curriculum and content, school and classroom learning environment, instructional and pedagogical practices, teachers' knowledge base and school culture. The third category considers social factors, related to home and family environment and relationships.

A total of 58 studies were identified that report on the factors influencing mathematics transition from primary to secondary school. Table 6 provides an overview of the

Table 5 Summary of reviewed studies on science transition

\begin{tabular}{|c|c|c|c|c|c|c|}
\hline \multirow[t]{2}{*}{ Key focus } & \multirow{2}{*}{$\begin{array}{l}\text { Number of } \\
\text { articles }\end{array}$} & \multicolumn{2}{|c|}{ Research design } & \multicolumn{3}{|c|}{ Research approach } \\
\hline & & Longitudinal & $\begin{array}{l}\text { Cross- } \\
\text { sectional }\end{array}$ & Quantitative & Qualitative & $\overline{\text { Mixed }}$ \\
\hline Academic context & 5 & 4 & 1 & 5 & 0 & 0 \\
\hline Learning environment & 5 & 2 & 3 & 0 & 2 & 3 \\
\hline Curriculum, content and pedagogy & 17 & 7 & 10 & 3 & 7 & 7 \\
\hline Teachers' influence & 2 & 0 & 2 & 0 & 1 & 1 \\
\hline Family externalization & 1 & 0 & 1 & 1 & 0 & 0 \\
\hline $\begin{array}{l}\text { Self-regulation and psychological, inter- } \\
\text { nalization }\end{array}$ & 15 & 5 & 10 & 8 & 3 & 4 \\
\hline Gender & 2 & 0 & 2 & 2 & 0 & 0 \\
\hline Total & 47 & 18 & 29 & 19 & 13 & 15 \\
\hline
\end{tabular}




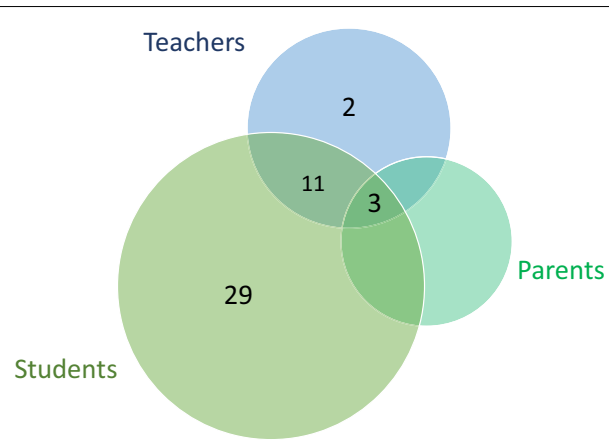

Fig. 5 Distribution of participants in study samples in science transition

9 factors identified under the three categories explained above.

\section{Student self-regulation factors}

Many studies reported negative self-image portrayed by students as they transition to secondary school. As a result, negative attitudes may develop towards mathematics (Silverthorn et al., 2005). These negative attitudes are accompanied by fear of guilt and rejection impacting students' willingness to engage in mathematics and/ or ask for assistance (Mudaly \& Sukhdeo, 2015) and are reported to be more prevalent in low-performing students (Smyth et al., 2004).

Skilling et al. (2020) investigated high- and lowachieving students' beliefs about mathematics learning and their experiences to explore shifts in their engagement levels as they transition to secondary school. They reported that 'engaged' students believed mathematics to be important for their future education and valued mathematics learning. These students had a preference for understanding over performance and had high levels of self-efficacy. In contrast, 'disengaged' students placed a lower value on mathematics learning and rated performance over understanding. Such students exhibited lower self-efficacy and negative emotions such as mathematics anxiety.

Beliefs of self-abilities such as self-efficacy, self-esteem and self-confidence that contribute to a sense of mathematical identity, shape positive or negative experiences of transition (Martin et al., 2015; Mudaly \& Sukhdeo, 2015). Higher self-efficacy and valuing of mathematics

Table 6 Factors influencing mathematics transition experiences

\begin{tabular}{|c|c|c|}
\hline Category & Influencing factors & Source of evidence \\
\hline \multirow[t]{2}{*}{ I. Student self-regulation } & $\begin{array}{l}\text { Attitudes (enjoyment, interest, } \\
\text { engagement) and motivation }\end{array}$ & $\begin{array}{l}\text { Athanasiou \& Philippou, 2010; Evans \& Field, 2020a, 2020b; Gasco Txabarri et al., 2014b } \\
\text {; Lazarides et al, 2020; Silverthorn et al., 2005; Skilling et al., 2020; Stroet et al., 2015; } \\
\text { Tytler et al., } 2008\end{array}$ \\
\hline & Identity development & $\begin{array}{l}\text { Athanasiou \& Philippou, 2010; Darragh, 2013; Evans et al., 2020; Gasco Txabarri et al., } \\
\text { 2014a; Jordan et al., 2010; Klee \& Miller, 2019; Lazarides et al., 2020; Ma \& Xu, 2004; } \\
\text { Madjar et al., 2018; Martin et al., 2015; Mudaly \& Sukhdeo, 2015; Muzzatti \& Agnoli, } \\
\text { 2007; Ryan \& Patrick, 2001; Silverthorn et al., 2005; Widlund et al., } 2018\end{array}$ \\
\hline \multirow[t]{5}{*}{ II. School related and academic } & Curriculum and content & $\begin{array}{l}\text { Bicknell \& Hunter, 2012; Deliyianni \& Gagatsis, 2013; Gniewosz et al., 2012; Jansen } \\
\text { et al., 2012; Ma \& Xu, 2004; Madjar et al., 2018; Prendergast et al., } 2019\end{array}$ \\
\hline & $\begin{array}{l}\text { Teachers' knowledge base, } \\
\text { communication and col- } \\
\text { laboration }\end{array}$ & $\begin{array}{l}\text { Attard, 2010; Demonty et al., 2018; Mudaly \& Sukhdeo, 2015; O'Meara et al., 2020a; } \\
\text { Prendergast et al., } 2019\end{array}$ \\
\hline & Instructional practices & $\begin{array}{l}\text { Arens \& Moller, 2016; Attard, 2010, 2011, 2012, 2013; Fryer \& Oga-Baldwin, 2019; How- } \\
\text { ard et al., 1997; Johnson et al., 2020; Mudaly \& Sukhdeo, 2015; O'Meara et al., 2020a; } \\
\text { Panaoura \& Gagatsis, 2010; Paul, 2014; Sdrolias \& Triandafillidis, 2008; Tytler et al., } 2008\end{array}$ \\
\hline & Classroom environment & $\begin{array}{l}\text { Anderman \& Midgley, 1997; Arens \& Moller, 2016; Athanasiou \& Philippou, 2006, 2008, } \\
\text { 2010; Bicknell \& Hunter, 2012; Deieso \& Fraser, 2019; Eccles et al., 1993; Friedel et al., } \\
\text { 2010; Fryer \& Oga-Baldwin, 2019; Lazarides et al., 2020; Lazarides et al., 2019; Mackay, } \\
\text { 2006; Martin et al., 2015; Mudaly \& Sukhdeo, 2015; Paul, 2014; Rice, 2001; Ryan \& } \\
\text { Patrick, } 2001\end{array}$ \\
\hline & School context/climate & $\begin{array}{l}\text { Carmichael, 2015; Carolan, 2013; Jansen et al., 2012; Jordan et al., 2010; Kieffer, 2013; } \\
\text { Madjar et al., 2018; Martin et al., 2015; Mudaly \& Sukhdeo, 2015; Rice, 2001; Wigfield } \\
\text { et al., } 1991\end{array}$ \\
\hline \multirow[t]{2}{*}{ III. Social } & Home and family environment & $\begin{array}{l}\text { Carmichael, 2015; Evans \& Field, 2020b; Evans et al., 2020; Friedel et al., 2010; Gniewosz } \\
\text { et al., 2012; Martin et al., 2015; Pesu et al., 2018; Rice, } 2001\end{array}$ \\
\hline & Relationships & $\begin{array}{l}\text { Arens \& Moller, 2016; Attard, 2010, 2011, 2012, 2013; Bicknell \& Hunter, 2012; Evans \& } \\
\text { Field, 2020a; Friedel et al., 2010; Gniewosz et al., 2012; Lazarides et al., 2019; Mackay, } \\
\text { 2006; Mudaly \& Sukhdeo, 2015; Semeraro et al., 2020; Stroet et al., 2015; Tytler et al., } \\
\text { 2008; Yao et al., } 2018\end{array}$ \\
\hline
\end{tabular}


are positively associated not only with engagement in secondary school mathematics (Martin et al., 2015), but also contributes to students' academic well-being and educational aspirations (Widlund et al., 2018). In a qualitative study by Darrragh (2013), excerpts from secondary students' interviews reflected a link between confidence of performing in mathematics and a sense of belonging in the class. Students reported a lack of belonging in the early stages of transition but gradually adjusted to 'fit' in the new environment, similar to what has been reported by other studies also (e.g. Mudaly \& Sukhdeo, 2015).

Mathematics anxiety is the most researched construct that influences identity formation during primary-secondary transition. Studies report that mathematics anxiety increases as students progress to secondary school. However, it gets stabilised or drops to the initial levels towards the end of the first year of transition (Darragh, 2013; Gasco Txabarri et al., 2014a; Madjar et al., 2018; Mudaly \& Sukhdeo, 2015). Klee and Miller (2019) in a longitudinal study in the US, explored group-based trajectories in mathematics anxiety at different time points from elementary to junior high school and found that there is no one common pattern of mathematics anxiety and it may constantly increase, decrease, fluctuate or even remain constant at all time points. Gender differences in mathematics anxiety have also been reported by some studies with girls experiencing higher math anxiety and lower self-efficacy than boys (Deieso \& Fraser, 2019; Klee \& Miller, 2019; Madjar et al., 2018).

\section{School-related and academic factors}

Studies have reported both positive and negative influences of school settings and culture on transition experiences of students. For example, those who transitioned between the schools showed greater mathematics anxiety in comparison to those who did not, i.e. remained in the same school after transition (Madjar et al., 2018). Some studies, on the contrary, found that institutional changes such as school culture and school size have little or no impact on students' mathematics progress as they transition to secondary school (Kieffer, 2013; Rice, 2001). Carmichael (2015) highlighted that the impact of school settings on mathematics achievement affects adversely only when the change is accompanied by significant curricular changes. Other influential factors related to school settings include larger class size in secondary school and fewer opportunities for student-teacher interaction (Mudaly \& Sukhdeo, 2015), excitement to be in a new school and being taught by specialist maths teachers (e.g. Bicknell \& Hunter, 2012).

Factors related to curriculum and content include increased workload in mathematics (more class work and homework), pace of study, lesser time for correctional work, longer duration of classes and independent academic performance (Attard, 2012; Mudaly \& Sukhdeo, 2015). These factors however may not contribute much to the difficulties associated with transition. Mudaly and Sukhdeo (2015) noted that despite increased workload reported by secondary students, they preferred high school for greater independence and freedom. In fact, it is the didactical practices and not the increased content/ workload that pose challenges to students (Attard, 2012; Mudaly \& Sukhdeo, 2015).

A large number of studies investigated factors related to classroom environment and its implications on students' mathematics learning. Findings from these studies suggest that aspects of classroom environment such as time for teacher-student interaction, teacher enthusiasm, perceived autonomy, class competition and perceived class performance are significantly related with secondary students' mathematics learning (Eccles et al., 1993; Fryer \& Oga-Baldwin, 2019; Lazarides et al., 2020; Mackay, 2006; Martin et al., 2015). In a longitudinal study in Cyprus, Athanasiou and Philippou (2010) followed 331 students over a period of two consecutive school years. The researchers reported that those who experienced a decline in aspects such as teacher friendliness, cooperation and interaction, after transition to a secondary school, reflected negative self-esteem and declined motivation. This incongruence between student-expected and the actual mathematics classroom environment has also been highlighted in other studies (Athanasiou \& Philippou, 2006, 2008; Bicknell \& Hunter, 2012; Eccles et al., 1993; Friedel et al., 2010; Martin et al., 2015). A comparison of classroom perceptions of 541 primary and secondary school students in Australia showed that secondary students perceived lesser involvement in mathematics classroom which resulted in deteriorated attitudes toward mathematics, decreased enjoyment and increased mathematics anxiety (Deieso \& Fraser, 2019).

Recent focus of research has however shifted on teachers' knowledge base (gap) and instructional and pedagogical practices employed in mathematics classrooms. A 2019 study on Irish teachers' views about issues related to primary-secondary transition highlighted a lack of knowledge of each other's curriculum and a lack of communication between teachers at both levels (Prendergast et al., 2019). A mismatch of pedagogical practices such as, different teaching practices, fast-paced teaching, and lack of drilling and revision in secondary school mathematics teaching has also been highlighted (Attard, 2012; Mudaly \& Sukhdeo, 2015; Paul, 2014; Powell et al., 2006). Another inconsistency is noted in the use of teaching aids in primary and secondary mathematics classrooms. For example, a recent study by O'Meara, Johnson and Leavy (2020b) found that the use of manipulatives in 
mathematics teaching is more frequent in primary classrooms than in the secondary classrooms. In their study, manipulatives were defined as 'concrete materials, and their virtual equivalents, that foster learning by engaging students physically and visually' (p.837). The researchers noted significant differences between primary and secondary teachers' confidence in the use of manipulatives. Similar results were reported in a 1997 Australian study that compared primary and secondary mathematics teachers' views on the usage of manipulatives in mathematics (Howard et al., 1997).

\section{Social factors}

Within the social factors, the role of relationships is the most researched. Positive relationship with peers has been recognised as a source of support that can enable successful transition for students (Ma \& Xu, 2004). Also, being accompanied by old friends after transition to a new school facilitated positive transition experiences in mathematics (Bicknell \& Hunter, 2012).

Student-teacher relationships is another influential construct that shapes students' experiences of mathematics transition. The quality of relationships with teachers has been found to have a direct influence on students' mathematics engagement and achievement (Attard, 2011, 2013; Semeraro et al., 2020). Positive relationships with teachers also help to develop students' socio-emotional skills and motivation for mathematics learning (Semeraro et al., 2020; Stroet et al., 2015). Additionally, secondary teachers' emphasis on mastery goals was found to promote higher self-efficacy in students (Friedel et al., 2010).

The reviewed studies also suggest that parental factors and home environment are strong predictors of mathematics engagement and achievement across transition. Using a secondary analysis of data from a national longitudinal study in the UK, Evans and Field (2020b) found that positive relationship with parents, level of parents' education and their school involvement play an influential role in mathematics attainment at the transition (at age 11). Additionally, parental emotional support, e.g. students' perceptions of their parents' valuing of mathematics is reported to be consistently associated with shifts in mathematics engagement (Martin et al., 2015). Furthermore, parents' own aspirations and their competence beliefs strongly impact their children's experiences of mathematics learning during the transitional phase (Becker \& Neumann, 2018; Gniewosz et al., 2012; Pesu et al., 2018). Greater emphasis by parents on 'mastery goals' (the extent to which children perceive an emphasis on learning and understanding) contributes to increased self-efficacy and motivation for mathematics learning (Friedel et al., 2010). Additionally, parents' involvement in non-school-related activities also influenced students' mathematics progress from primary to secondary school (Rice, 2001; Smyth et al., 2004). Other home-related factors such as number of siblings and socio-economic status were reported to have only a little effect on transition experiences (Rice, 2001).

\section{Research Question 2. What factors influence students' experiences of science transition from primary to secondary school?}

28 studies were identified that addressed the factors influencing students' experiences of science transition. Table 7 lists the factors identified within the 3 categories described above.

\section{Student self-regulation factors}

Studies identified in this category suggest that as students transition to secondary school, they may acquire negative attitudes towards science and feel less motivated to engage in science learning (Bae \& DeBusk-Lane, 2018). Hasni et al. (2017) noted that secondary students generally consider science subjects to be more important than social sciences and arts but less important than mathematics and English. Furthermore, boys considered science to be easier compared with other subjects, than girls. Gender differences have also been noted in relation to science aspirations for the future, with higher science aspirations expressed by boys than girls (DeWitt et al., 2014). The preferences and interest in science is also related to students' academic performance at the school level (Bae \& DeBusk-Lane, 2018; Ohle et al., 2015). Studies also suggest a close link between students' science interest and classroom practices. In a UK study, Braund and Driver (2005) noted a link between science interest and practical work done in science class. It was noted that primary school students enjoyed practical work in science and expected secondary school science to be more enjoyable in terms of experimentation and handson activities. While the style of instruction influences situational interest which is temporary, it has implications for the development of individual interest which is a long term and stable construct (Trobst et al., 2016).

Research has also noted a correlation between positive self-perceptions of ability and science achievement (Silverthorn et al., 2005). Self-regulating factors such as the ability to adjust and stress management also influence students' experiences of transition to secondary school. The transition phase is found to be generally easier for those with good social and emotional adaptability skills (Jordan et al., 2010).

\section{School-related and academic factors}

Within the school-related factors, the majority of the studies explored aspects of science classroom 
Table 7 Factors influencing science transition experiences

\begin{tabular}{|c|c|c|}
\hline Category & Influencing factors & Source of evidence \\
\hline \multirow[t]{2}{*}{ I. Student self-regulation } & $\begin{array}{l}\text { Attitudes (enjoyment, interest, } \\
\text { engagement) and motivation }\end{array}$ & $\begin{array}{l}\text { Bae \& DeBusk-Lane, 2018; Braund \& Driver, 2005; Campbell, 2001; DeWitt et al., 2014; } \\
\text { Hasni et al., 2017; Ohle et al., 2015; Trobst et al., 2016; Tytler et al., 2008; Varley et al., } \\
\text { 2013; Wang \& Lin, } 2009\end{array}$ \\
\hline & Identity development & $\begin{array}{l}\text { DeWitt et al., 2014; Jordan et al., 2010; Morgan et al., 2016; Senler \& Sungur, 2009; } \\
\text { Silverthorn et al., } 2005\end{array}$ \\
\hline \multirow[t]{5}{*}{ II. School related and academic } & Curriculum and content & $\begin{array}{l}\text { Morgan et al., 2016; Nakhleh et al., 2005; Opitz et al., 2015; Saat, 2010; Speering \& Ren- } \\
\text { nie, 1996; Varley et al., } 2013\end{array}$ \\
\hline & $\begin{array}{l}\text { Teachers' knowledge base, } \\
\text { communication and col- } \\
\text { laboration }\end{array}$ & Ohle et al., 2015 \\
\hline & Instructional practices & $\begin{array}{l}\text { Aker \& Ellis, 2019; Akuma and Callaghan, 2019; Campbell, 2001; Fadzil \& Saat, 2014a, } \\
\text { 2014b; Logan \& Skamp, 2008; Powell et al., 2006; Speering \& Rennie, 1996; Trobst et al., } \\
\text { 2016; Tytler et al., 2008; Varley et al., 2013; Wang \& Lin, } 2009\end{array}$ \\
\hline & Classroom environment & $\begin{array}{l}\text { Aker \& Ellis, 2019; Braund \& Driver, 2005; Ferguson \& Fraser, 1998; Rice, 2001; Wang \& } \\
\text { Lin, } 2009\end{array}$ \\
\hline & School context/climate & Alspaugh, 1998; Carolan, 2013; Morgan et al., 2016; Speering \& Rennie, 1996 \\
\hline \multirow[t]{2}{*}{ III. Social } & Home and family environment & DeWitt \& Archer, 2015; Morgan et al., 2016; Senler \& Sungur, 2009 \\
\hline & Relationships & Ferguson \& Fraser, 1998; Speering \& Rennie, 1996; Thurston et al., 2010a, 2010b \\
\hline
\end{tabular}

environment, instructional practices, and specific topics of science curriculum. 22 studies reported on schoolrelated factors.

A positive correlation between classroom learning environment and students' science attitudes has been reported (Wang \& Lin, 2009). However, studies highlight a mismatch between student-expected and the actual learning environment in secondary science classrooms (Campbell, 2001; Saat, 2010; Speering \& Rennie, 1996; Wang \& Lin, 2009). These studies reported students' negative experiences of science transition on account of their perceived dissatisfaction with the traditional learning environment and lack of practical teaching approaches in secondary school science classrooms. Gender differences in how the learning environment is perceived by students has also been highlighted. For instance, while boys prioritised activities in secondary school, girls were more concerned about their relationships with friends and teachers (Ferguson \& Fraser, 1998).

12 out of 22 studies explored the role of instructional practices in shaping students' experiences of science transition from primary to secondary school. Evidence from these studies suggest the importance of conducting practical experiments and inquiry-based hands-on activities to enhance students' interest and engagement in science (Logan \& Skamp, 2008; Trobst et al., 2016; Varley et al., 2013). However, lack of such opportunities for students, e.g. 'a dominance of prescribed, teacher-directed practical work over independently planned pupil investigations' (Varley et al., 2013, p.284), excessive note copying reported by secondary students (Logan \& Skamp, 2008), lesser use of manipulative skills for science instruction
(Fadzil \& Saat, 2014a, 2014b) and teacher-centred learning in secondary classroom (Wang \& Lin, 2009) is highlighted. Research has noted that formal teaching methods impede the growth of conceptual knowledge and understanding of the relevance of science in daily life (Saat, 2010). Pedagogies that provide opportunities for active classroom participation and social communication (with peers and teachers) instil greater positive attitudes towards science learning (Wang \& Lin, 2009).

A smaller number of studies also explored students' acquisition of content knowledge for specific topics such as heat, matter or energy concepts and the progression of their understanding in these concepts as they move from primary to secondary school (Nakhleh et al., 2005; Opitz et al., 2015; Saat, 2010). These studies highlight a lack of conceptual understanding in science and a gap between students' general knowledge and scientific knowledge as they transition to secondary school. Only one study (Ohle et al., 2015) from the review investigated teachers' content knowledge (CK) in physics and explored its impact on students' interest. Teachers' self-interest in physics positively predicted their content knowledge of physics. However, no association was found between teachers' CK and students' interest in physics.

\section{Social factors}

Only six studies reported on factors related to home and family environment and relationships with peers and teachers. Three studies investigated the factors related to home and family environment (Morgan et al., 2016; Senler \& Sungur, 2009). Findings from these studies suggest that factors such as quality of parenting, parental 
involvement in school activities, parents' education, and the level of family income are the key factors influencing children's science-related beliefs and their science achievement. Furthermore, parents' attitudes towards school science impacts their children's science aspirations for the future (DeWitt \& Archer, 2015). However, positive parental attitudes may not always translate to positive science aspirations of children-an important factor is whether or not parents work in science-related jobs (DeWitt \& Archer, 2015).

Peer relationships were also found to be very influential in promoting positive transition experiences. Investigating the role of cooperative learning strategies in science across the transition, Thurston et al. (2010a) noted that 'Pupils tended to focus peer relationships on pupils with whom they worked, rather than more generally with the class' (p. 30). Two studies (Ferguson \& Fraser, 1998; Speering \& Rennie, 1996) reported on the influence of student-teacher relationships on students' experiences of science transition. These studies reported that change in student-teacher relationship was the most difficult one for students when they moved to secondary school. Secondary school students felt a lack of personal interaction with their teachers and reported decreased motivation for learning. These relationship concerns were more prominent in girls, reporting higher levels of dissatisfaction than boys.

\section{Research Question 3. What are the implications of the factors that influence students' experiences in mathematics across the transition from primary to secondary school?}

A total number of 41 studies were identified that explored the impact of factors that influence students' mathematics transition to secondary school. Table 8 shows the implications of transition evidenced in the reviewed studies.

The most prominent impact of students' (negative) transition experiences, as evidenced from the review, is on students' mathematics achievement. Nearly $40 \%$ of the studies reviewed under this section reported a significant dip in mathematics achievement as students transition to secondary school. It has been asserted that trajectories in mathematics achievement follow a rise-hold-loss pattern, meaning that students show higher mathematics achievement in primary school, remain neutral in middle school and the achievement levels decline in high school (Lee, 2010). Evidence from reviewed studies also suggest that transition solely cannot be associated with declined achievement rather various other contextual factors may come into play. A significant (though small) effect of the impact of mathematics attitudes, school affect, teacher characteristics and working memory on mathematics attainment trajectories have been established (Evans \& Field, 2020a; Evans et al., 2020). Carmichael (2015) reported only a small effect of transition on mathematics achievement after controlling for factors of age, sex and parental wealth. Changes in curriculum and pedagogical practices rather than the move to a different school was reported as a major factor that influences students' academic achievement.

Another significant impact of primary-secondary transition that emerged from the review is a shift in students' attitudes and motivation in mathematics. More than half of the studies reported a decline in attitudes relating to motivation and engagement and beliefs of mathematics self-abilities in secondary school students. It has been noted that secondary school students show decreased persistence, lesser positive attitudes to mathematical inquiry, describe mathematics as less valuable and perceive lesser enjoyment in mathematics than primary school students (Deieso \& Fraser, 2019; Pajares \& Graham, 1999). Martin et al. (2015) reported significant decline in students' mathematics engagement after transition, but the decline was found to be associated with student, home and classroom factors rather than the transition itself.

Table 8 Implications of mathematics transition experiences

\begin{tabular}{ll}
\hline Implications of factors & Source of evidence \\
\hline Impact on mathematics achievement & Anderman \& Midgley, 1997; Carmichael, 2015; Carolan, 2013; Evans \& Field, 2020b; Lazarides et al., 2020; Lee, \\
& 2010; Mackay, 2006; Mudaly \& Sukhdeo, 2015; Pajares \& Graham, 1999; Paul, 2014; Rice, 1997; Semeraro et al., \\
& 2020; Smyth et al., 2004; Whitley et al., 2007; Widlund et al., 2018; Yao et al., 2018 \\
& Anderman \& Midgley, 1997, 2004; Athanasiou \& Philippou, 2006, 2008, 2010; Attard, 2010, 2012, 2013; Darragh, \\
& 2013; Eccles et al., 1993; Friedel et al., 2010; Galton et al., 2003; Jansen et al., 2012; Lazarides, et al., 2019; Martin \\
& et al., 2015; Mudaly \& Sukhdeo, 2015; Pajares \& Graham, 1999; Paul, 2014; Widlund et al., 2018 \\
& Arens et al., 2013; Athanasiou \& Philippou, 2010; Becker \& Neumann, 2018; Darragh, 2013; Entwisle et al.., 1994; \\
& Field et al., 2019; Friedel et al., 2010; Gniewosz et al., 2012; Ma \& Xu, 2004; Madjar et al., 2018; Muzzatti \& Agnoli, \\
& 2007; Pajares \& Graham, 1999; Pesu et al., 2018; Suren \& Kandemir, 2020; Widlund et al., 2018; Wigfield et al., \\
& 1991; Yao et al., 2018 \\
\hline
\end{tabular}


Studies also provide evidence of the impact of transition on aspects related to the development of mathematical identities of students. For example, decline in self-concept and confidence (Darragh, 2013; Widlund et al., 2018), incline in negative self-esteem (Athanasiou \& Philippou, 2010) and increased mathematics anxiety (Madjar et al., 2018) after transition to secondary school have been noted. A significant influence on students' selfefficacy beliefs was found to be predicted by students' perceptions of their teachers' and parents' emphasis on mastery and performance goals (Friedel et al., 2010). Gender seems to play a significant role in the development of mathematical identities. It is documented that girls experience greater decline in self-esteem resulting in higher levels of mathematics anxiety than boys (Ma \& $\mathrm{Xu}$, 2004; Madjar et al., 2018; Suren \& Kandemir, 2020). Evidence also suggests that mathematics anxiety not only influences the school transitional phase, but it can have long-lasting consequences. Findings from a recent UK study by Field et al. (2019) report that pre-transition levels of anxiety and changes during transition are significant predictors of mathematics anxiety at age 18 . Additionally, this study reported that mathematics attainment (prior to transition and its trajectories across the transition) also predicts later mathematics anxiety.

\section{Research Question 4. What are the implications of the factors that influence students' experiences in science across the transition from primary to secondary school?}

19 publications in science transition were mapped with this research question to explore the implications of students' transition experiences in science. The review studies provided evidence for significant decline in science achievement when students transition from primary to secondary school (Alspaugh, 1998; Bae \& DeBusk-Lane, 2018; Morgan et al., 2016; Powell et al., 2006; Rice, 1997, 2001). A longitudinal study by Morgan et al. (2016) in the US reported that large science achievement gaps emerge at an early age and persist till the end of eight grade. In their study, student's prior general knowledge emerged as the strongest predictor of these achievement gaps in science. Parental influences such as home environment and the quality of parenting were also associated with academic achievement (ibid). Table 9 lists the implications of science transition evidenced in the reviewed literature.

The review studies also report a shift in students' attitudes and engagement in science as they transition from primary to secondary school. For instance, science interest and motivation decline significantly in secondary school (Anderhag et al., 2016; Hasni et al., 2017; Reid \& Skryabina, 2003; Speering \& Rennie, 1996; Trobst et al., 2016; Varley et al., 2013). Anderhag et al. (2016), however, argued that there is a possibility that there is no loss of interest when students enter secondary school rather the interest was not even developed in the first instance. The researchers criticised heavy reliance of research on interviews and questionnaires, doubting the reliability of results. In contrast, Logan and Skamp (2008), in their longitudinal study of students' science engagement in Australia, found that most of the students in secondary school showed positive attitudes towards science. This was attributed to students' perceived enjoyment in practical science work and use of new laboratory equipment in secondary school. However, they also acknowledged the possibility of the 'Hawthorne effect' where 'the researcher may have influenced student interest by giving credence to student voice... helping students see the value in school science.' (pp. 516-517).

Evidence also highlights the effect of transition experiences on constructs related to the development of students' scientific identities. Lofgran et al. (2015) measured science self-efficacy of students at two transition points-from elementary to middle school and from middle to high school in the US. Their analysis found gradual declines in self-efficacy scores as students progressed from elementary to middle school, with significant declines observed in the ninth grade (high school). Considerable differences in students' science aspirations before and after transition have also been noted (Speering \& Rennie, 1996). On the other hand, it has been argued that there is a disconnect between attitudes to school science and aspirations for future science. Positive science attitudes in school may not necessarily

Table 9 Implications of science transition experiences

\begin{tabular}{ll}
\hline Implications of factors & Source of evidence \\
\hline Impact on science achievement & Alspaugh, 1998; Bae \& DeBusk-Lane, 2018; Morgan et al., 2016; Powell et al., 2006; Rice, 1997, 2001 \\
Shifts in attitudes and motivation & Aker \& Ellis, 2019; Anderhag et al., 2016; Barmby et al., 2008; Galton et al., 2003; Hasni et al., 2017; \\
& Logan \& Skamp, 2008; Martin et al., 2020; Ohle et al., 2015; Reid \& Skryabina, 2003; Senler \& Sun- \\
& gur, 2009; Speering \& Rennie, 1996; Trobst et al., 2016 \\
Identity development & Barmby et al., 2008; DeWitt \& Archer, 2015; DeWitt et al., 2014; Lofgran et al., 2015; Reid \& Skrya- \\
& bina, 2003; Speering \& Rennie, 1996; Trobst et al., 2016 \\
\hline
\end{tabular}


translate to future aspirations for science-related careers (DeWitt et al., 2014). Martin et al. (2020) also noted that decreased science engagement was evident only in school and not in terms of students' aspirations for choosing science careers or science-related activities outside school. Additionally, consistent findings were noted in terms of gender differences in various constructs of identity development. Girls' attitudes seem to be particularly affected after their transition to secondary school. For example, girls expressed lesser science self-efficacy (Lofgran et al., 2015), greater declines in science interest (Barmby et al., 2008; Reid \& Skryabina, 2003; Speering \& Rennie, 1996; Trobst et al., 2016) and lower science aspirations than boys (DeWitt et al., 2014; Speering \& Rennie, 1996).

\section{Research Questions 5: What measures have been used} to support students in mathematics and science transitions from primary to secondary school?

From a total of 73 publications on mathematics transition selected for the review, only three could be mapped with this research question (Table 10). In comparison, review studies on science transition included a greater proportion of studies focused on measures to facilitate transition experiences of students. 11 out of 47 selected publications in science provide evidence of measures taken for supporting students across primary to secondary school transition (Table 11). The studies mapped with this section are listed in Tables 10 and 11 .

Two approaches to these measures were identified: a) theoretical measures and b) empirical measures.

\section{Theoretical measures}

One study on mathematics transition by Cantley et al. (2020) addressed transition via theoretical measures. The authors provide a framework for analysing continuity in student learning across mathematics transition from primary to secondary school. The framework models five hierarchical levels-Implemented curriculum, Pedagogy, School, Society and Civilisation for transition from primary to secondary level mathematics. While the first two levels ensure didactical continuity in students' learning experiences, the third, fourth and fifth levels in the model would operate differently in different contexts.

\section{Empirical measures}

These include measures such as an intervention or an experiment focused on content and pedagogical practices and the effectiveness is measured via participants' experiences before and after the intervention. All but one study mapped with this research question addressed transition via these measures. In mathematics, two studies report on the evaluation of a professional development programme for teachers-one of which focused on enhanc-

Table 10 Brief overview of studies on facilitating mathematics transition

\begin{tabular}{lll}
\hline Author(s) & Study context & Focus \\
\hline Beesley et al. (2018) & US & Formative assessment-professional development program for teachers \\
Cantley et al. (2020) & Ireland & A framework for analysing mathematics continuity from primary to secondary school \\
Fernandez and Anhalt (2001) & US & Transition towards algebra-professional development program for teachers \\
\hline
\end{tabular}

Table 11 Brief overview of studies on facilitating science transition

\begin{tabular}{|c|c|c|}
\hline Author(s) & Study context & Focus \\
\hline Braund (2007) & United Kingdom & Bridging work in science programme-scientific inquiry \\
\hline Davies and McMahon (2004) & United Kingdom & $\begin{array}{l}\text { Joint planning and implementation of link project by primary and } \\
\text { secondary teachers }\end{array}$ \\
\hline McCormack et al. (2014) & Ireland & Cognitive development during transition \\
\hline Braund (2016) & United Kingdom & Investigation skills in science \\
\hline McCormack (2016) & Ireland & Cognitive development during transition \\
\hline Braund and Hames (2005) & United Kingdom & Bridging units programme-scientific inquiry \\
\hline Morgan (2013) & Australia & Explicit teaching of technical language to improve scientific literacy \\
\hline Thurston et al. (2010a, 2010b) & United Kingdom & Cooperative learning in science \\
\hline Scharf and Schibeci (1990) & Australia & Transition units as curricular reform—science attitudes \\
\hline Kerr (2016) & Northern Ireland & Outdoor science learning \\
\hline
\end{tabular}

ing formative assessment practices to encourage student 
engagement and persistence and the other focused on effective teaching strategies for transition to algebra. In contrast, studies in science mostly investigated the effectiveness of bridging units in the form of small lessons/ tasks to facilitate the gap between primary and secondary science. Positive impacts of these interventions in terms of students' attitudes to science and teachers' confidence were reported.

Although STEM integration has been increasingly emphasised in international education policies, no studies in this review reported on measures integrating mathematics and science learning to address the challenges in relation to transition between primary and second level.

\section{Discussion}

This review identified three key factors that influence students' experiences in mathematics and science across their transition from primary to secondary school-student self-regulation factors, school and academic related factors, and social factors. Findings suggest that students' experiences of transition in these subjects cannot be attributed to any single factor as various contextual factors may come into play. For example, mathematics attainment trajectories from primary to secondary school are impacted by a multitude of factors such as mathematics attitudes, school affect, teacher characteristics and working memory (Evans \& Field, 2020a; Evans et al., 2020). Figure 6 summarises the factors that have been found to influence the experiences of students across mathematics and science transition from primary to secondary school (Research Questions 1 \&2).

The most common focus of research in both the disciplines appears to be in the category of school-related factors wherein classroom learning environment is the most investigated. A major inconsistency lies in curricular and pedagogical practices employed in primary and secondary classrooms. While students expect secondary classroom learning to be more hands-on and activity-oriented, it is not always the case. This incongruence between student-expected and the actual classroom environment negatively impacts student engagement and motivation in mathematics and science learning. Also, the majority of the studies report negative experiences of students and factors contributing to positive experiences are relatively less discussed, confirming similar findings from previous reviews on general transition from primary to secondary school (Bharara, 2020; Jindal-Snape et al., 2019).

The review found relatively less research on the social factors, i.e., the role of relationships, family and home environment in science than mathematics. Availability of less literature in science than mathematics on familyrelated factors was also noted by Goos et al. (2020) in their study on gender balance in STEM. Nonetheless, this review provides ample evidence to suggest that family and friends play an influential role in students' interface with mathematics and science as they transition to their secondary school.

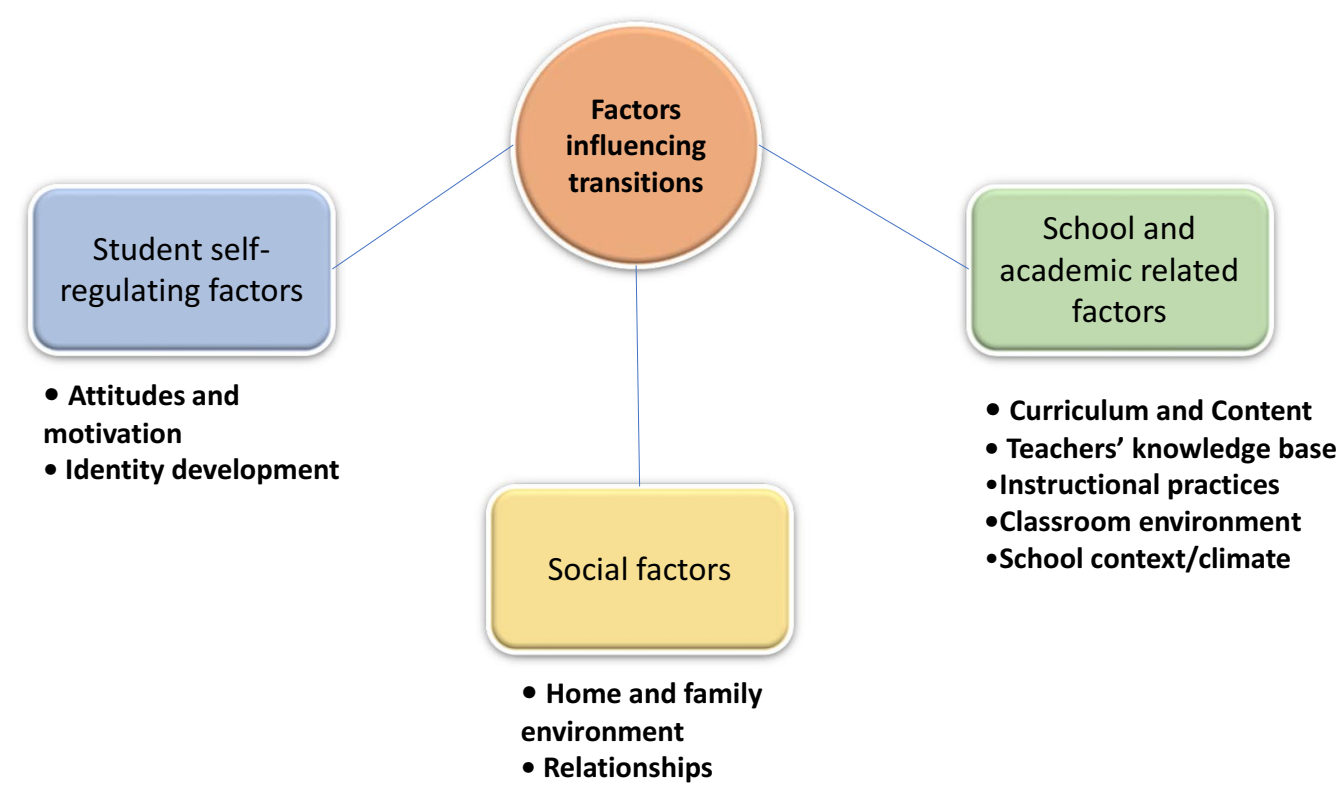

Fig. 6 Factors influencing students' experiences of mathematics and science transition 




Fig. 7 Implications of mathematics and science transition experiences of students

The implications of the factors that affect students' experiences of mathematics and science across this transition (Research Questions 3 \& 4) are illustrated in Fig. 7.

A significant impact of these combined factors is a shift in students' attitudes and motivation in learning. More than half of the studies in this review presented evidence of a decrease in student motivation and engagement and an increase in negative attitudes towards mathematics and science among secondary school students. The reviewed studies also indicate that students' performance in mathematics and science declines as they transition to their secondary school which echoes the findings from other reviews on general transition (Jindal-Snape et al., 2019; McGee et al., 2003). One striking observation is that while many studies in mathematics address mathematics anxiety and investigate it as a factor as well as an impact of transition, no studies in science bring up the issue of science anxiety although decreased science interest and engagement have been reported. This is noteworthy as psychological well-being is an important factor in the development of students' mathematics and scientific identities and requires further research.

Whilst many studies in this review addressed research questions 1-4, studies that reported on effective measures to support mathematics and science transitions (research question 5) are limited, highlighting the need for further research in this area. Furthermore, these measures reported in the reviewed studies have dealt with mathematics and science disciplines separately.
An integrated approach for the teaching and learning of mathematics and science disciplines emerged as a gap in the literature on school transition.

It is also interesting to note that even though separate analyses of the studies reviewed in mathematics and science were conducted, similar findings were obtained in relation to the factors that influence students' experiences in these two subjects and the implications of these factors. This presents a strong rationale for the integration of mathematics and science to address the challenges faced by students in these two subjects across the transition.

\section{Recommendations and conclusions}

Findings of this review clearly indicate that most of the existing research identifies that mathematics and science transitions from primary to secondary school are associated with many challenges and negative experiences of students. These negative experiences act as barriers to students' learning and result in disengagement and disinterest for these subjects. The findings of this systematic review offer recommendations for policy and curriculum development, learning environment, teacher education and curriculum structure.

\section{i) Increased curricular and pedagogical continuity}

Addressing the negative factors identified in this study requires a greater focus on the continuity between primary and secondary curricula. This continuity needs to be explicitly presented in curricular specifications at both 
primary and secondary level. Improved coherence in learning and teaching approaches at both levels can support student engagement in mathematics and science. In addition, increased alignment between primary and secondary curricula can also improve pedagogical continuity across this transition.

\section{ii) Positive learning environments}

This review highlights the influence of student self-regulation skills on their experiences of mathematics and science learning across transitions. Creating a supportive learning environment is a significant factor for the development of student's key skills and attitudes, such as motivation and resilience for learning, and beliefs of selfesteem and self-concept (Athanasiou \& Philippou, 2010). Learning environments where students do not worry about making mistakes increase students' enjoyment and self-confidence (Kaur \& Prendergast, 2021), promote a growth mindset and foster resilience for learning (Fraser, 2018). Therefore, greater consideration should be given to creating and promoting positive learning environments that help develop students' self-regulating skills to support their transition from primary to secondary school.

\section{iii) A greater focus on teacher collaboration and professional learning}

Establishing professional learning communities that bring together primary and secondary mathematics and science teachers could lead to increased collaboration and communication between teachers and enable sharing of instructional and pedagogical practices. Findings of this review suggest that school-related factors, such as communication and collaboration between teachers, curricular and pedagogical inconsistencies have significant influence on mathematics and science transitions. Further research is needed to examine the impact of greater continuity between curricular and pedagogical approaches used in primary and secondary classrooms.

\section{iv) Addressing social factors}

Interventions that focus on addressing social factors such as peer relationships, parental influences and studentteacher relationships are needed. These may include measures such as increased parental involvement and measures that provide greater emotional support to students. Promoting student and teacher engagement in reflective practices may also help to develop positive identities of students.

\section{Contributions and implications for future research}

As noted in this review, integrated learning approaches in mathematics and science for addressing the challenges of primary-secondary transition are under researched. Future research is needed to explore how integration between mathematics and science disciplines at the school level can facilitate smooth transitions from primary to secondary education. Further studies are needed to examine the impact of explicit connections between mathematics and science for promoting student interest and engagement in these subjects. Further research is also needed to examine student learning when explicit connections are made between mathematics and science.

The findings also suggest a dearth of international comparative studies on mathematics and science transitions from primary to secondary school. The reviewed literature contained only one cross-border study by O'Meara et al. (2020a) where teachers' perceptions of mathematical knowledge for teaching at the transition were examined cross sectionally from Northern Ireland and Republic of Ireland. It is recommended that future research focuses on international comparisons of the challenges and positive experiences of students and teachers across primary-secondary school transition. Such studies will promote international collaboration to share examples and evidence of best practices to support students during their transition phase. Additionally, the reviewed literature discussed negative experiences more than the positive experiences. Future research should also capture students' experiences or perceptions of what worked well to support their transition journey meaningfully.

There are potential limitations in the generalisability or transferability of findings of this review. The review included studies that were published in English language only. Studies in other languages may have significant findings which could be a potential lack of evidence to the results. Another limitation is that even though the search strings were applied carefully for database searches, some relevant studies could have been left. Also, while utmost attention and objectivity was ensured by the researchers during the selection and analysis of studies, there is a possibility that some significant studies may have been missed. The findings of the current study should be interpreted in light of these limitations. Despite these limitations, the breadth of the research reviewed provided a broad understanding of the landscape of mathematics and science transitions from primary to secondary school. It is hoped that the findings of this review will inform further research and planning of measures/interventions to support transitions across primary-secondary mathematics and science. Finally, this review did not 
include studies which focused on mathematics and science transition experiences of specialised or vulnerable young people. This could be an area of future research.

\author{
Abbreviations \\ CK: Content knowledge; OECD: Organisation for Economic Co-operation and \\ Development; PISA: Programme for International Student Assessment; STEM: \\ Science, Technology, Engineering, and Mathematics; TIMSS: Trends in Interna- \\ tional Mathematics and Science Study.
}

\section{Acknowledgements}

Not Applicable.

\section{Authors' contributions}

All authors contributed to the design and execution of this study. Search terms were agreed upon by all authors and TK performed database searches with agreed-upon search terms. The identification of themes, selection of publications and coding process was carried out collaboratively by TK, EM and PG. TK led on the analysis of selected publications with support of EM and PG and findings were discussed and agreed by all authors. All authors read and approved the final manuscript.

\section{Funding}

This work was supported by the Erasmus + KA201 programme of the European Union under Grant agreement number 2020-1-IE01-KA201-066069.

\section{Availability of data and materials}

Studies selected for this review can be found through reverse citation lookup. The following databases were used to find studies within the review: Academic Search Complete, Education research complete, British Education Index, Education Research Information Center (ERIC), and PsycINFO via EBSCOhost, Web of Science and Google Scholar.

\section{Declarations}

\section{Competing interests}

The authors declare that they have no competing interests.

\section{Author details}

${ }^{1}$ Centre for the Advancement of STEM Teaching and Learning and School of STEM Education, Innovation and Global Studies, DCU Institute of Education, Dublin City University, Dublin, Ireland. ${ }^{2}$ Centre for the Advancement of STEM Teaching and Learning and School of Physical Sciences, Dublin City University, Dublin, Ireland.

Received: 20 Auqust 2021 Accepted: 11 January 2022

Published online: 04 February 2022

\section{References}

Aarnos, E., \& Perkkila, P. (2012). Early signs of mathematics anxiety? Procedia Social and Behavioral Sciences, 46, 1495-1499. https://doi.org/10.1016/j. sbspro.2012.05.328

Aker, L. B., \& Ellis, A. K. (2019). A Meta-Analysis of Middle School Students' Science Engagement. International Dialogues on Education: Past and Present, 6(1), 9-24. https://doi.org/10.53308/ide.v6i1.46

Akuma, F. V., \& Callaghan, R. (2019). Teaching practices linked to the implementation of inquiry-based practical work in certain science classrooms. Journal of Research in Science Teaching, 56(1), 64-90. https://doi.org/10 1002/tea.21469

Alspaugh, J. W. (1998). Achievement Loss Associated with the Transition to Middle School and High School. The Journal of Educational Research, 92(1), 20-25. https://doi.org/10.1080/00220679809597572

Anderhag, P., Wickman, P.-O., Bergqvist, K., Jakobson, B., Hamza, K. M., \& Säljö, R. (2016). Why do secondary school students lose their interest in science? Or does it never emerge? A possible and overlooked explanation. Science Education, 100(5), 791-813. https://doi.org/10.1002/sce.21231
Anderman, E. M., \& Midgley, C. (1997). Changes in achievement goal orientations, perceived academic competence, and grades across the transition to middle-level schools. Contemporary Educational Psychology, 22(3), 269-298. https://doi.org/10.1006/ceps.1996.0926

Anderman, E. M., \& Midgley, C. (2004). Changes in self-reported academic cheating across the transition from middle school to high school. Contemporary Educational Psychology, 29(4), 499-517. https://doi.org/ 10.1016/j.cedpsych.2004.02.002

Anderson, J., English, L., Fitzallen, N.. \& Symons, D. (2020). The contribution of mathematics education researchers to the current STEM education agenda. In Research in Mathematics Education in Australasia 2016-2019 (pp. 27-57). Springer, Singapore. https://doi.org/10.1007/ 978-981-15-4269-5 3

Archer, L., DeWitt, J., Osborne, J., Dillon, J., Willis, B., \& Wong, B. (2010). "Doing" science versus "being" a scientist: Examining 10/11-year-old schoolchildren's constructions of science through the lens of identity. Science Education, 94(4), 617-639. https://doi.org/10.1002/sce.20399

Arens, A. K., \& Moller, J. (2016). Dimensional comparisons in students' perceptions of the learning environment. Learning and Instruction, 42, 22-30. https://doi.org/10.1016/j.learninstruc.2015.11.001

Arens, A. K., Yeung, A. S., Nagengast, B., \& Hasselhorn, M. (2013). Relationship between self-esteem and academic self-concept for German elementary and secondary school students. Educational Psychology, 33(4), 443-464. https://doi.org/10.1080/01443410.2013.772772

Athanasiou, C., \& Philippou, G. N. (2006). Motivation and perceptions of classroom culture in mathematics of students across grades 5 to 7 . In J. Novotna, H. Moraova, M. Kratka, \& N. Stehlikova (Eds.), Pme 30: Proceedings of the 30th Conference of the International Group for the Psychology of Mathematics Education, 2, 81-88. https://eric.ed.gov/?id=ED496932

Athanasiou, C., \& Philippou, G. N. (2008). Classroom environment fit in mathematics across the transition from primary to secondary school. In O. Figueras, J. L. Cortina, S. Alatorre, T. Rojano, \& A. Sepulveda (Eds.), Proceedings of the Joint Meeting of PME 32 and PME-NA XXX, Vol 2 (pp. 105-112).

Athanasiou, C., \& Philippou, G. N. (2010). The effects of changes in the perceived classroom social culture on motivation in mathematics across transitions. Cerme 6 - Proceedings of the 6th Congress of the European Society for Research in Mathematics Education, 114-123. Retrieved from $<$ Go to ISI >://WOS:000393368800014

Attard, C. (2010). Students' experiences of mathematics during the transition from primary to secondary school. Paper presented at the 33rd annual conference of the Mathematics Education Research Group of Australasia, Fremantle, Perth.

Attard, C. (2011). Engagement with mathematics: The influence of teachers. Southeast Asian Mathematics Education Journal, 1(1), 31-39. https://doi. org/10.46517/seamej.v1i1.8

Attard, C. (2012). Transition from primary to secondary school mathematics: Students' perceptions. Southeast Asian Mathematics Education Journal, 2(1), 31-43. https://doi.org/10.46517/seamej.v2i1.16

Attard, C. (2013). "If I had to pick any subject, it wouldn't be maths": Foundations for engagement with mathematics during the middle years. Mathematics Education Research Journal, 25(4), 569-587. https://doi.org/ 10.1007/s13394-013-0081-8

Bae, C. L., \& DeBusk-Lane, M. (2018). Motivation belief profiles in science: Links to classroom goal structures and achievement. Learning and Individual Differences, 67, 91-104. https://doi.org/10.1016/j.lindif.2018.08.003

Barmby, P., Kind, P. M., \& Jones, K. (2008). Examining Changing Attitudes in Secondary School Science. International Journal of Science Education, 30(8), 1075-1093. https://doi.org/10.1080/09500690701344966

Becker, M., \& Neumann, M. (2018). Longitudinal big-fish-little-pond effects on academic self-concept development during the transition from elementary to secondary schooling. Journal of Educational Psychology, 110(6), 882-897. https://doi.org/10.1037/edu0000233

Beesley, A. D., Clark, T. F., Dempsey, K., \& Tweed, A. (2018). Enhancing formative assessment practice and encouraging middle school mathematics engagement and persistence. School Science and Mathematics, 118(1-2), 4-16. https://doi.org/10.1111/ssm.12255

Bharara, G. (2020). Factors facilitating a positive transition to secondary school: A systematic literature review. International Journal of School \& Educational Psychology, 8(sup1), 104-123. https://doi.org/10.1080/21683603. 2019.1572552 
Bicknell, B., \& Hunter, R. (2012). School Transition from Year 6 to Year 7: A Focus on Mathematics. International Journal for Mathematics Teaching and Learning. Retrieved from https://www.cimt.org.uk/journal/hunter.pdf

Braund, M. (2016). Oh no, not this again! Improving continuity and progression from primary to secondary science. School Science Review, 98(362), 19-26. Retrieved from https://www.academia.edu/28535165/Science_ during_primary_secondary_transition

Braund, M. (2007). "Bridging work" and its role in improving progression and continuity: An example from science education. British Educational Research Journal, 33(6), 905-926. https://doi.org/10.1080/0141192070 1657025

Braund, M., \& Driver, M. (2005). Pupils' perceptions of practical science in primary and secondary school: Implications for improving progression and continuity of learning. Educational Research, 47(1), 77-91. https:// doi.org/10.1080/0013188042000337578

Braund, M., \& Hames, V. (2005). Improving progression and continuity from primary to secondary science: Pupils' reactions to bridging work. International Journal of Science Education, 27(7), 781-801. https://doi.org/10. 1080/09500690500038405

Bybee, R. W. (2013). The case for STEM education: Challenges and opportunities. NSTA Press. https://doi.org/10.2505/9781936959259

Campbell, B. (2001). Pupils' perceptions of science education at primary and secondary school. In Research in science education-past, present, and future (pp. 125-130). Springer, Dordrecht. https://doi.org/10.1007/0306-47639-8_16

Cantley, I., O'Meara, N., Prendergast, M., Harbison, L., \& O'Hara, C. (2020). Framework for analysing continuity in students' learning experiences during primary to secondary transition in mathematics. Irish Educational Studies, 40(1), 37-49. https://doi.org/10.1080/03323315.2020.1779108

Carmichael, C. (2015). Transitioning to secondary school: The case of mathematics. Australian Journal of Educational and Developmental Psychology, 15, 13-23. Retrieved from <Go to $|S|>$ ://WOS:000384153600002

Carolan, B. V. (2013). School Transitions and Students' Achievement in the Fifth Grade. Journal of Educational Research, 106(5), 372-383. https://doi.org/ $10.1080 / 00220671.2012 .736432$

Clewell, B. C., \& Campbell, P. B. (2002). Taking stock: Where we've been, where we are, where we're going. Journal of Women and Minorities in Science and Engineering, 8(3-4), 30. https://doi.org/10.1615/JWomenMinorScie nEng.v8.i3-4.20

Darragh, L. (2013). Constructing confidence and identities of belonging in mathematics at the transition to secondary school. Research in Mathematics Education, 15(3), 215-229. https://doi.org/10.1080/14794802. 2013.803775

Davies, D., \& McMahon, K. (2004). A smooth trajectory: Developing continuity and progression between primary and secondary science education through a jointly-planned projectiles project. International Journal of Science Education, 26(8), 1009-1021. https://doi.org/10.1080/14681 81032000158372

Deieso, D., \& Fraser, B. J. (2019). Learning Environment, Attitudes and Anxiety across the Transition from Primary to Secondary School Mathematics. Learning Environments Research, 22(1), 133-152. https://doi.org/10. 1007/s10984-018-9261-5

Deliyianni, E., \& Gagatsis, A. (2013). Tracing the development of representational flexibility and problem solving in fraction addition: A longitudinal study. Educational Psychology, 33(4), 427-442. https://doi.org/10.1080/ 01443410.2013 .765540

Demonty, I., Vlassis, J., \& Fagnant, A. (2018). Algebraic thinking, pattern activities and knowledge for teaching at the transition between primary and secondary school. Educational Studies in Mathematics, 99, 1. https://doi. org/10.1007/s10649-018-9820-9

DES (2017). STEM Education policy statement 2017-2026. Dublin: Department of Education and Skills.

Devine, A., Hill, F., Carey, E., \& Szücs, D. (2018). Cognitive and emotional math problems largely dissociate: Prevalence of developmental dyscalculia and mathematics anxiety. Journal of Educational Psychology, 110(3), 431-444. https://doi.org/10.1037/edu0000222

DeWitt, J., \& Archer, L. (2015). Who aspires to a science career? A comparison of survey responses from primary and secondary school students. International Journal of Science Education, 37(13), 2170-2192. https://doi. org/10.1080/09500693.2015.1071899
DeWitt, J., Archer, L., \& Osborne, J. (2014). Science-related Aspirations Across the Primary-Secondary Divide: Evidence from two surveys in England. International Journal of Science Education, 36(10), 1609-1629. https://doi. org/10.1080/09500693.2013.871659

Eccles, J. S., Wigfield, A., Midgley, C., Reuman, D., Maciver, D., \& Feldlaufer, H. (1993). Negative effects of traditional middle schools on students' motivation. Elementary School Journal, 93(5), 553-574. https://doi.org/ $10.1086 / 461740$

English, L. D. (2016). STEM education K-12: Perspectives on integration. International Journal of STEM Education, 3(1), 1-8. https://doi.org/10.1186/ s40594-016-0036-1

Entwisle, D. R., Alexander, K. L., \& Olson, L. S. (1994). The gender-gap in math - its possible origins in neighborhood effects. American Sociological Review, 59(6), 822-838. https://doi.org/10.2307/2096370

European Commission. (2018). Council recommendation on key competences for lifelong learning. Retrieved from https://ec.europa.eu/education/educa tion-in-the-eu/council-recommendation-on-key-competences-for-lifel ong-learning_en

Evangelou, M., Taggart, B., Sylva, K., Melhuish, E., Sammons, P. \& Siraj-Blatchford, I. (2008). Effective pre-school, primary and secondary education 3-14 project (EPPSE 3-14): What makes a successful transition from primary to secondary school? (London, Institute of Education, University of London, Department for Children, Schools and Families).

Evans, D., \& Field, A. P. (2020a). Maths attitudes, school affect and teacher characteristics as predictors of maths attainment trajectories in primary and secondary education: Predictors of Maths Trajectories. Royal Society Open Science, 7, 10. https://doi.org/10.1098/rsos.200975

Evans, D., \& Field, A. P. (2020b). Predictors of mathematical attainment trajectories across the primary-to-secondary education transition: Parental factors and the home environment: Predictors of maths attainment. Royal Society Open Science, 7, 7. https://doi.org/10.1098/rsos.200422rsos 200422

Evans, D., Gaysina, D., \& Field, A. P. (2020). Internalizing symptoms and working memory as predictors of mathematical attainment trajectories across the primary-secondary education transition. Royal Society Open Science, 7, 5. https://doi.org/10.1098/rsos.191433

Fadzil, H. M., \& Saat, R. M. (2014a). Enhancing STEM education during school transition: Bridging the gap in science manipulative skills. Eurasia Journal of Mathematics, Science and Technology Education, 10(3), 209-218. https://doi.org/10.12973/eurasia.2014.1071a

Fadzil, H. M., \& Saat, R. M. (2014b). Exploring the Influencing Factors in Students' Acquisition of Manipulative Skills during Transition from Primary to Secondary School. Asia-Pacific Forum on Science Learning and Teaching, 15, 2.

Ferguson, P. D., \& Fraser, B. J. (1998). Student Gender, School Size and Changing Perceptions of Science Learning Environments during the Transition from Primary to Secondary School. Research in Science Education, 28(4), 387-397. https://doi.org/10.1007/BF02461506

Fernandez, M. L., \& Anhalt, C. O. (2001). Transition Toward Algebra. Mathematics Teaching in the Middle School, 7(4), 236-241. https://doi.org/10.5951/ mtms.7.4.0236

Field, A. P., Evans, D., Bloniewski, T., \& Kovas, Y. (2019). Predicting maths anxiety from mathematical achievement across the transition from primary to secondary education. Royal Society Open Science, 6, 11. https://doi.org/ 10.1098/rsos.191459

Fitzallen, N. (2015). STEM education: What does mathematics have to ofer? In M. Marshman (Ed.), Mathematics education in the margins. Proceedings of the 38th annual conference of the Mathematics Education Research Group of Australasia (pp. 237-244). Sydney: MERGA

Fraser, B. J., Tobin, K., \& McRobbie, C. J. (Eds.). (2012). Second international handbook on science education. Springer.

Fraser, D. M. (2018). An exploration of the application and implementation of growth mindset principles within a primary school. The British Journal of Educational Psychology, 88(4), 645-658. https://doi.org/10.1111/bjep. 12208

Friedel, J. M., Cortina, K. S., Turner, J. C., \& Midgley, C. (2010). Changes in efficacy beliefs in mathematics across the transition to middle school: Examining the effects of perceived teacher and parent goal emphases. Journal of Educational Psychology, 102(1), 102-114. https://doi.org/10.1037/ a0017590 
Fryer, L. K., \& Oga-Baldwin, W. L. Q. (2019). Succeeding at junior high school: Students' reasons, their reach, and the teaching that h(inders)elps their grasp. Contemporary Educational Psychology. https://doi.org/10.1016/j. cedpsych.2019.101778

Galton, M., Hargreaves, L., \& Pell, T. (2003). Progress in the middle years of schooling: Continuities and discontinuities at transfer. Education, 31(2), 9-18. https://doi.org/10.1080/03004270385200161

Gasco Txabarri, J., Goni, A., \& Villarroel, J. D. (2014a). Sex differences in mathematics motivation in 8th and 9th grade. In J. C. Laborda, F. Ozdamli, \&Y. Maasoglu (Eds.), 5th World Conference on Educational Sciences, 116, 1026-1031. https://doi.org/10.1016/j.sbspro.2014.01.340

Gasco Txabarri, J., Villarroel, J. D., \& Goni, A. (2014b). Differences in the use of learning strategies in mathematics in 8th and 9th grade. In J. C. Laborda, F. Ozdamli, \& Y. Maasoglu (Eds.), 5th World Conference on Educational Sciences, 116, pp. 1040-1043. https://doi.org/10.1016/j.sbspro. 2014.01.342

Gniewosz, B., Eccles, J. S., \& Noack, P. (2012). Secondary school transition and the use of different sources of information for the construction of the academic self-concept. Social Development, 21(3), 537-557. https://doi. org/10.1111/j.1467-9507.2011.00635.x

Goos, M., Ryan, V., Lane, C., Leahy, K., Walsh, G., O'Connell, T., ... \& Nizar, A. (2020). Review of Literature to Identify a Set of Effective Interventions for Addressing Gender Balance in STEM in Early Years, Primary and PostPrimary Education Settings. Department of Education and Skills.

Hammond, N. (2016). Making a drama out of transition: Challenges and opportunities at times of change. Research Papers in Education, 31(3), 299-315. https://doi.org/10.1080/02671522.2015.1029963

Hasni, A., Potvin, P., \& Belletête, V. (2017). The Status of Science and Technology Relative to Other School Subjects. Results of a Study Conducted on Primary and Secondary School Students in Quebec. EURASIA Journal of Mathematics, Science \& Technology Education, 13(6), 1575-1603. https:// doi.org/10.12973/eurasia.2017.00686a

Honey, M., Pearson, G., \& Schweingruber, H. (Eds.). (2014). STEM integration in K-12 education: Status, prospects, and an agenda for research (Vol. 500). Washington, DC: The National Academies Press. https://doi.org/10. 17226/18612

Howard, P., Perry, B., \& Tracey, D. (1997). Mathematics and manipulatives: Comparing primary and secondary teachers'views. Paper presented at the annual conference of the Australian Association for Research in Education, Brisbane.

Hurley, M. M. (2001). Reviewing integrated science and mathematics: The search for evidence and definitions from new perspectives. School Science and Mathematics, 101(5), 259-268. https://doi.org/10.1111/j. 1949-8594.2001.tb18028

Jansen, A., Herbel-Eisenmann, B., \& Smith, J. P. I. (2012). Detecting students' experiences of discontinuities between middle school and high school mathematics programs: Learning during boundary crossing. Mathematical Thinking and Learning, 14(4), 285-309. https://doi.org/10.1080/ 10986065.2012 .717379

Jenkins, E. W., \& Nelson, N. W. (2005). Important but not for me: Students' attitudes towards secondary school science in England. Research in Science \& Technological Education, 23(1), 41-57. https://doi.org/10.1080/ 02635140500068435

Jindal-Snape, D., Cantali, D., MacGillivray, S. \& Hannah, E. (2019) Primary to secondary school transitions: Systematic literature review (Edinburgh, The Scottish Government).

Jindal-Snape, D., \& Foggie, J. (2008). A holistic approach to primary-secondarytransitions. Improving Schools, 11(1), 5-18. https://doi.org/10.1177/ 1365480207086750

Johnson, P., O'Meara, N., \& Leavy, A. (2020). Factors supporting and inhibiting teachers' use of manipulatives around the primary to post-primary education transition. International Journal of Mathematical Education in Science and Technology, 52(7), 1006-1028. https://doi.org/10.1080/ 0020739x.2020.1736348

Jordan, J.-A., McRorie, M., \& Ewing, C. (2010). Gender differences in the role of emotional intelligence during the primary-secondary school transition. Emotional \& Behavioural Difficulties, 15(1), 37-47. https://doi.org/10. 1080/13632750903512415

Kaur, T., \& Prendergast, M. (2021). Students' perceptions of mathematics writing and its impact on their enjoyment and self-confidence. Teaching Mathematics and lts Applications. https://doi.org/10.1093/teamat/hrab008
Keay, A., Lang, J., \& Frederickson, N. (2015). Comprehensive support for peer relationships at secondary transition. Educational Psychology in Practice, 37(3), 279-292. https://doi.org/10.1080/02667363.2015.1052046

Kelley, T. R., \& Knowles, J. G. (2016). A conceptual framework for integrated STEM education. International Journal of STEM Education, 3(11), 1-11. https://doi.org/10.1186/s40594-016-0046-z

Kerr, K. (2016). Science Learning in the Outdoors to Support Primary-Secondary Transition. School Science Review, 98(362), 27-32. Retrieved from https://pureadmin.qub.ac.uk/ws/portalfiles/portal/94470059/Science_ learning.pdf

Kieffer, M. (2013). Development of Reading and Mathematics Skills in Early Adolescence: Do K-8 Public Schools Make a Difference? Journal of Research on Educational Effectiveness, 6, 361-379. https://doi.org/10. 1080/19345747.2013.822954

Klee, H. L., \& Miller, A. D. (2019). Moving up! Or down? Mathematics anxiety in the transition from elementary school to junior high. The Journal of Early Adolescence, 39(9), 1311-1336. https://doi.org/10.1177/0272431618 825358

Lazarides, R., Dicke, A. L., Rubach, C., \& Eccles, J. S. (2020). Profiles of motivational beliefs in math: Exploring their development, relations to student-perceived classroom characteristics, and impact on future career aspirations and choices. Journal of Educational Psychology, 112(1), 70-92. https://doi.org/10.1037/edu0000469

Lazarides, R., Gaspard, H., \& Dicke, A. L. (2019). Dynamics of classroom motivation: Teacher enthusiasm and the development of math interest and teacher support. Learning and Instruction, 60, 126-137. https://doi.org/ 10.1016/j.learninstruc.2018.01.012

Lee, J. (2010). Tripartite growth trajectories of reading and math achievement: Tracking national academic progress at primary, middle, and high school levels. American Educational Research Journal, 47(4), 800-832. https://doi.org/10.3102/0002831210365009

Lindahl, B. (2007). A longitudinal study of students' attitudes towards science and choice of career. NARST Annual Conference, April 15-18, 2007, New Orleans. http://urn.kb.se/resolve?urn=urn:nbn:se:hkr:diva-6093

Lofgran, B. B., Smith, L. K., \& Whiting, E. F. (2015). Science Self-Efficacy and School Transitions: Elementary School to Middle School, Middle School to High School. School Science and Mathematics, 115(7), 366-376. https://doi.org/10.1111/ssm.12139

Logan, M., \& Skamp, K. (2008). Engaging students in science across the primary secondary interface: Listening to the students' voice. Research in Science Education, 38(4), 501-527. https://doi.org/10.1007/s11165-007-9063-8

Lyons, T., \& Quinn, F. (2010). Choosing Science: Understanding the declines in senior high school science enrolments. National Centre of Science, ICT and Mathematics Education for Rural and Regional Australia, University of New England, Armidale.

Ma, X., \& Xu, J. (2004). The Causal Ordering of Mathematics Anxiety and Mathematics Achievement: A Longitudinal Panel Analysis. Journal of Adolescence, 27(2), 165-179. https://doi.org/10.1016/j.adolescence. 2003.11 .003

Maass, K., Geiger, V., Ariza, M. R., \& Goos, M. (2019). The Role of Mathematics in interdisciplinary STEM education. ZDM Mathematics Education, 51(6), 869-884. https://doi.org/10.1007/s11858-019-01100-5

Mackay, I. F. (2006). Classroom factors supporting progress in mathematics. In J. Novotna, H. Moraova, M. Kratka, \& N. Stehlikova (Eds.), PME 30: Proceedings of the 30th Conference of the International Group for the Psychology of Mathematics Education, 4, 105-112.

Mackenzie, E., McMaugh, A., \& O'Sullivan, K. (2012). Perceptions of primary to secondary school transitions: Challenge or threat? Issues in Educational Research, 22(3), 298-314.

Madjar, N., Zalsman, G., Weizman, A., Lev-Ran, S., \& Shoval, G. (2018). Predictors of developing mathematics anxiety among middle-school students: A 2-year prospective study. International Journal of Psychology, 53(6), 426-432. https://doi.org/10.1002/ijop.12403

Margot, K. C., \& Kettler, T. (2019). Teachers' perception of STEM integration and education: A systematic literature review. International Journal of STEM Education, 6, 1. https://doi.org/10.1186/s40594-018-0151-2

Martin, A. J., Way, J., Bobis, J., \& Anderson, J. (2015). Exploring the ups and downs of mathematics engagement in the middle years of school. The Journal of Early Adolescence, 35(2), 199-244. https://doi.org/10.1177/ 0272431614529365 
Martin, K. M., Davis, L. S., \& Sandretto, S. (2020). Engagement with Science Across the Middle Years in New Zealand. New Zealand Journal of Educational Studies, 56(1), 83-99. https://doi.org/10.1007/s40841-020-00185-x

McCormack, L. (2016). The Use of CASE to Bridge the Transition between Primary and Secondary School Science in Ireland. School Science Review, 98(362), 47-54. Retrieved from https://bura.brunel.ac.uk/bitstream/ 2438/13364/1/Fulltext.pdf

McCormack, L., Finlayson, O. E., \& McLoughlin, T. J. (2014). The case programme implemented across the primary and secondary school transition in Ireland. International Journal of Science Education, 36(17), 2892-2917. https://doi.org/10.1080/09500693.2014.938711

McGee, C., Ward, R., Gibbons, J., \& Harlow, A. (2003). Transition to secondary school: A literature review. A Report to the Ministry of Education. Hamilton, University of Waikato, New Zealand.

McLoughlin, E., Butler, D., Kaya, S., \& Costello, E. (2020). STEM education in schools: What can we learn from the research? ATS STEM Report \#1. Ireland: Dublin City University. https://doi.org/10.5281/zenodo.3673728

Morgan, A.M. (2013).'Proof of concept': Beginning to use Design-Based Research to improve science literacies for middle years learners. Australian Journal of Lanquage \& Literacy, 36(1), 3-16. https://hdl.handle.net/ $1959.11 / 12285$

Morgan, P. L., Farkas, G., Hillemeier, M. M., \& Maczuga, S. (2016). Science Achievement Gaps Begin Very Early, Persist, and Are Largely Explained by Modifiable Factors. Educational Researcher, 45(1), 18-35. https://doi. org/10.3102/0013189X16633182

Mudaly, V., \& Sukhdeo, S. (2015). Mathematics Learning in the Midst of School Transition from Primary to Secondary School. International Journal of Educational Sciences, 11(3), 244-252. https://doi.org/10.1080/09751122. 2015.11890395

Mullis, I.V.S., Martin, M.O., Foy, P., \& Arora, A. (2012). TIMSS 2011 international results in mathematics. Chestnut Hill, MA: TIMSS and PIRLS International Study Centre, Boston College.

Mullis, I. V. S., Martin, M. O., Foy, P., Kelly, D. L., \& Fishbein, B. (2020). TIMSS 2019 International Results in Mathematics and Science. Retrieved from Boston College, TIMSS \& PIRLS International Study Center website: https://timss andpirls.bc.edu/timss2019/international-results/

Mumford, J., \& Birchwood, J. (2020). Transition: A systematic review of literature exploring the experiences of pupils moving from primary to secondary school in the UK. Pastoral Care in Education. https://doi.org/10.1080/ 02643944.2020 .1855670

Murphy, C., Mullaghy, M., \& D'Arcy, A. (2016). 'Scientists are not always right, but they do their best.' Irish children's perspectives of innovations in science teaching and learning. School Science Review, 98(362), 55-65. Retrieved from https://www.academia.edu/31304963/SSR_September_2016

Muzzatti, B., \& Agnoli, F. (2007). Gender and mathematics: Attitudes and stereotype threat susceptibility in Italian children. Developmental Psychology, 43(3), 747-759. https://doi.org/10.1037/0012-1649.43.3.747

Nakhleh, M. B., Samarapungavan, A., \& Saglam, Y. (2005). Middle school students' beliefs about matter. Journal of Research in Science Teaching, 42(5), 581-612. https://doi.org/10.1002/tea.20065

OECD. (2016). PISA 2015 Results (Volume I): Excellence and Equity in Education. PISA, OECD Publishing, Paris, https://doi.org/10.1787/9789264266 490-en

OECD. (2019a). PISA 2018 Results (Volume I): What Students Know and Can Do. PISA, OECD Publishing, Paris, https://doi.org/10.1787/5f07c754-en

OECD. (2019b). PISA 2018 Results (Volume II): Where All Students Can Succeed. PISA, OECD Publishing, Paris, https://doi.org/10.1787/b5fd1 b8f-en

Ohle, A., Boone, W. J., \& Fischer, H. E. (2015). Investigating the impact of teachers' physics CK on students outcomes. International Journal of Science and Mathematics Education, 13(6), 1211-1233. https://doi.org/10.1007/ s10763-014-9547-8

O'Meara, N., Prendergast, M., Cantley, I., Harbison, L., \& O'Hara, C. (2020). Teachers'self-perceptions of mathematical knowledge for teaching at the transition between primary and post-primary school. International Journal of Mathematical Education in Science and Technology, 51(4), 497-519. https://doi.org/10.1080/0020739X.2019.1589004

O'Meara, N., Johnson, P., \& Leavy, A. (2020). A comparative study investigating the use of manipulatives at the transition from primary to post-primary education. International Journal of Mathematical Education in Science and Technology, 51(6), 835-857. https://doi.org/10.1080/0020739x.2019. 1634842
Opitz, S. T., Harms, U., Neumann, K., Kowalzik, K., \& Frank, A. (2015). Students' Energy Concepts at the Transition Between Primary and Secondary School. Research in Science Education, 45(5), 691-715. https://doi.org/10. 1007/s11165-014-9444-8

Osborne, J., Simon, S., \& Collins, S. (2003). Attitudes towards science: A review of the literature and its implications. International Journal of Science Education, 25(9), 1049-1079. https://doi.org/10.1080/095006903200003 2199

Pajares, F., \& Graham, L. (1999). Self-efficacy, motivation constructs, and mathematics performance of entering middle school students. Contemporary Educational Psychology, 24(2), 124-139. https://doi.org/10.1006/ ceps.1998.0991

Panaoura, G., \& Gagatsis, A. (2010). The geometrical reasoning of primary and secondary school students. In Proceedings of the Sixth Congress of the European Society for Research in Mathematics (pp. 746-755).

Patrick, H., \& Mantzicopoulos, P. (2015). Young Children's Motivation for Learning Science. In K. Cabe Trundle \& M. Saçkes (Eds.), Research in Early Childhood Science Education (pp. 7-34). Springer Netherlands. https:// doi.org/10.1007/978-94-017-9505-0_2

Paul, M. (2014). Managing the transition from primary school mathematics to secondary school mathematics: Teachers'and learners' perspectives. Mediterranean Journal of Social Sciences, 5(25), 205. https://doi.org/10. 5901/mjss.2014.v5n25p205

Perkins, R., Shiel, G., Cosgrove, J., Merriman, B., \& Moran, G. (2013). Learning for life: The achievements of 15-year olds in Ireland on mathematics, reading literacy and science in PISA 2012. Dublin: Educational Research Centre. http://www.erc.ie/documents/p12main_report.pdf

Pesu, L., Aunola, K., Viljaranta, J., Hirvonen, R., \& Kiuru, N. (2018). The role of mothers' beliefs in students' self-concept of ability development. Learning \& Individual Differences, 65, 230-240. https://doi.org/10.1016/j.lindif. 2018.05.013

Potvin, P., \& Hasni, A. (2014). Analysis of the Decline in Interest Towards School Science and Technology from Grades 5 Through 11. Journal of Science Education and Technology, 23(6), 784-802. https://doi.org/10.1007/ s10956-014-9512-x

Powell, R., Smith, R., Jones, G., \& Reakes, A. (2006). Transition from primary to secondary school: Current arrangements and good practice in Wales. Final Report. Slough: NFER.

Prendergast, M., O'Meara, N., O'Hara, C., Harbison, L., \& Cantley, I. (2019). Bridging the primary to secondary school mathematics divide: Teachers' perspectives. Issues in Educational Research, 29(1), 243-260. http://hdl. handle.net/10344/7515

Ramirez, G., Gunderson, E. A., Levine, S. C., \& Beilock, S. L. (2013). Math anxiety, working memory, and math achievement in early elementary school. Journal of Cognition and Development, 14(2), 187-202. https://doi.org/ 10.1080/15248372.2012.664593

Regan, E., \& DeWitt, J. (2015). Attitudes, Interest and Factors Influencing STEM Enrolment Behaviour: An Overview of Relevant Literature. In E. K. Henriksen, J. Dillon, \& J. Ryder (Eds.), Understanding Student Participation and Choice in Science and Technology Education. Springer Netherlands. https://doi.org/10.1007/978-94-007-7793-4_5

Reid, N., \& Skryabina, E. A. (2003). Gender and physics. International Journal of Science Education, 25(4), 509-536. https://doi.org/10.1080/0950069022 000017270

Rice, J. K. (1997). The disruptive transition from middle to high school: Opportunities for linking policy and practice. Journal of Education Policy, 12(5), 403-417. https://doi.org/10.1080/0268093970120508

Rice, J. K. (2001). Explaining the Negative Impact of the Transition From Middle to High School on Student Performance in Mathematics and Science. Educational Administration Quarterly, 37(3), 372-400. https://doi.org/10. $1177 / 00131610121969352$

Ritz, J. M., \& Fan, S. C. (2015). STEM and technology education: International state-of-the-art. International Journal of Technology and Design Education, 25(4), 429-451. https://doi.org/10.1007/s10798-014-9290-z

Ryan, A. M., \& Patrick, H. (2001). The Classroom Social Environment and Changes in Adolescents' Motivation and Engagement during Middle School. American Educational Research Journal, 38(2), 437-460. https:// doi.org/10.3102/00028312038002437

Saat, R. M. (2010). Progression or regression? Children's understanding of the heat concept from primary to secondary school. Paper presented at the 1st 
World Conference on Learning, Teaching and Administration, WCLTA2010, Cairo.

Scharf, P. F., \& Schibeci, R. A. (1990). The influence of a 'Transition Science' unit on student attitudes. Research in Science \& Technological Education, 8(1), 79-88. https://doi.org/10.1080/0263514900080109

Sdrolias, K. A., \& Triandafillidis, T. A. (2008). The Transition to Secondary School Geometry: Can There Be a'Chain of School Mathematics'? Educational Studies in Mathematics, 67(2), 159-169. https://doi.org/10.1007/ s10649-007-9093-1

Semeraro, C., Giofrè, D., Coppola, G., Lucangeli, D., \& Cassibba, R. (2020). The role of cognitive and non-cognitive factors in mathematics achievement: The importance of the quality of the student-teacher relationship in middle school. PLOS ONE, 15(4), 1-22. https://doi.org/10.1371/journ al.pone. 0231381

Senler, B., \& Sungur, S. (2009). Parental Influences on Students' Self-Concept, Task Value Beliefs, and Achievement in Science. Spanish Journal of Psychology, 12(1), 106-117. https://doi.org/10.1017/s1138741600001529

Silverthorn, N., DuBois, D. L., \& Crombie, G. (2005). Self-Perceptions of Ability and Achievement across the High School Transition: Investigation of a State-Trait Model. Journal of Experimental Education, 73(3), 191-218. https://doi.org/10.3200/jexe.73.3.191-218

Skilling, K., Bobis, J., \& Martin, A. J. (2020). The "ins and outs" of student engagement in mathematics: shifts in engagement factors among high and low achievers. Mathematics Education Research Journal. https://doi.org/ 10.1007/s13394-020-00313-2

Smyth, E., McCoy, S., \& Darmody, M. (2004). Moving up: The experiences of firstyear students in post-primary education. Liffey Press.

Speering, W., \& Rennie, L. (1996). Students' perceptions about science: The impact of transition from primary to secondary school. Research in Science Education, 26(3), 283-298. https://doi.org/10.1007/BF02356940

Stroet, K., Opdenakker, M.-C., \& Minnaert, A. (2015). What motivates early adolescents for school? A longitudinal analysis of associations between observed teaching and motivation. Contemporary Educational Psychology, 42, 129-140. https://doi.org/10.1016/j.cedpsych.2015.06.002

Suren, N., \& Ali Kandemir, M. (2020). The effects of mathematics anxiety and motivation on students' mathematics achievement. International Journal of Education in Mathematics, Science and Technology, 8(3), 190-218. https://doi.org/10.46328/JJEMST.V813.926

Symonds, J., \& Galton, M. (2014). Moving to the next school: An international review of adolescent psychological development at school transition. Review of Education, 2(1), 1-27. https://doi.org/10.1002/rev3.3021

Symonds, J., \& Hargreaves, L. (2016). Emotional and motivational engagement at school transition: A qualitative stage-environment fit study. The Journal of Early Adolescence, 36(1), 54-85. https://doi.org/10.1177/02724 31614556348

Tai, R. H., Qi Liu, C., Maltese, A. V., \& Fan, X. (2006). Career choice. Planning early for careers in science. Science, 312(5777), 1143-1144. https://doi.org/10. 1126/science. 1128690

Thurston, A., Christie, D., Karagiannidou, E., Tolmie, A., Murray, P., \& Topping, K. (2010a). Enhancing outcomes in school science for pupils during transition from elementary school using cooperative learning. Middle Grades Research Journal, 5(1), 19-32. http://eric.ed.gov/?id=EJ888658

Thurston, A., Topping, K. J., Tolmie, A., Christie, D., Karagiannidou, E., \& Murray, P. (2010b). Cooperative learning in science: Follow-up from primary to high school. International Journal of Science Education, 32(4), 501-522. https://doi.org/10.1080/09500690902721673

Topping, K. (2011). Primary-Secondary Transition: Differences between Teachers' and Children's Perceptions. Improving Schools, 14(3), 268-285. https://doi.org/10.1177/1365480211419587

Tranfield, D., Denyer, D., \& Smart, P. (2003). Towards a Methodology for Developing Evidence-Informed Management Knowledge by Means of Systematic Review. British Journal of Management, 14(3), 207-222. https://doi.org/10.1111/1467-8551.00375

Tröbst, S., Kleickmann, T., Lange-Schubert, K., Rothkopf, A., \& Möller, K. (2016). Instruction and Students' Declining Interest in Science: An Analysis of German Fourth- and Sixth-Grade Classrooms. American Educational Research Journal, 53(1), 162-193. https://doi.org/10.3102/0002831215 618662

Tytler, R., \& Osborne, J. (2012). Student attitudes and aspirations towards science. In Second International Handbook of Science Education. https://doi. org/10.1007/978-1-4020-9041-7_41
Tytler, R., Osborne, J. F., Williams, G., Tytler, K., Clark, J. C., Tomei, A., et al. (2008). Opening up pathways: Engagement in STEM across the Primary-Secondary school transition. A review of the literature concerning supports and barriers to Science, Technology, Engineering and Mathematics engagement at Primary-Secondary transition. Commissioned by the Australian Department of Education, Employment and Workplace Relations. Melbourne: Deakin University.

van Rens, M., Haelermans, C., Groot, W., \& Maassen van den Brink, H. (2018). Facilitating a Successful Transition to Secondary School: (How) Does it Work? A Systematic Literature Review. Adolescent Research Review, 3(1), 43-56. https://doi.org/10.1007/s40894-017-0063-2

Varley, J. P., Murphy, C., \& Veale, Ó. (2013). At the Crossroads: The Impact of New Irish Science Curricula on First Year Post-Primary Students. Research in Science Education, 43(1), 275-298. https://doi.org/10.1007/ s11165-011-9252-3

Wang, J. R., \& Lin, S. W. (2009). Evaluating elementary and secondary school science learning environments in Taiwan. International Journal of Science Education, 31(7), 853-872. https://doi.org/10.1080/09500690701636361

Wang, M.-T., Eccles, J. S., \& Kenny, S. (2013). Not Lack of Ability but More Choice: Individual and Gender Differences in Choice of Careers in Science, Technology, Engineering, and Mathematics. Psychological Science, 24(5), 770-775. https://doi.org/10.1177/0956797612458937

West, P., Sweeting, H., \& Young, R. (2010). Transition matters: Pupils' experiences of the primary secondary school transition in the West of Scotland and consequences for well-being and attainment. Research Papers in Education, 25(1), 21-50. https://doi.org/10.1080/02671520802308677

Whitley, J., Lupart, J. L., \& Beran, T. (2007). Differences in achievement between adolescents who remain in a K-8 school and those who transition to a junior high school. Canadian Journal of Education, 30(3), 649-669. https://doi.org/10.2307/20466657

Widlund, A., Tuominen, H., \& Korhonen, J. (2018). Academic well-being, mathematics performance, and educational aspirations in lower secondary education: Changes within a school year. Frontiers in Psychology. https:// doi.org/10.3389/fpsyg.2018.00297

Wigfield, A., Eccles, J. S., Mac Iver, D., Reuman, D. A., \& Midgley, C. (1991). Transitions during early adolescence: Changes in children's domain-specific self-perceptions and general self-esteem across the transition to junior high school. Developmental Psychology, 27(4), 552-565. https://doi.org/ 10.1037/0012-1649.27.4.552

Yao, Y. L., Kong, Q. P., \& Cai, J. F. (2018). Investigating Elementary and Middle School Students' Subjective Well-Being and Mathematical Performance in Shanghai. International Journal of Science and Mathematics Education, 16(S1), 107-127. https://doi.org/10.1007/s10763-017-9827-1

Zeedyk, M. S., Gallacher, J., Henderson, M., Hope, G., Husband, B., \& Lindsay, K. (2003). Negotiating the transition from primary to secondary school: Perceptions of pupils, parents and teachers. School Psychology International, 24(1), 67-79. https://doi.org/10.1177/0143034303024001010

\section{Publisher's Note}

Springer Nature remains neutral with regard to jurisdictional claims in published maps and institutional affiliations.

\section{Submit your manuscript to a SpringerOpen ${ }^{\odot}$ journal and benefit from:}

- Convenient online submission

- Rigorous peer review

- Open access: articles freely available online

- High visibility within the field

- Retaining the copyright to your article

Submit your next manuscript at $\boldsymbol{\nabla}$ springeropen.com 